\title{
$\mathrm{UiO}$ : Det juridiske fakultet
}

\section{Retten til inntektsfradrag for utgifter til sponsing}

Kandidatnummer: 640

Leveringsfrist: 25.11 .12

Antall ord: 15461 


\section{Innholdsfortegnelse}

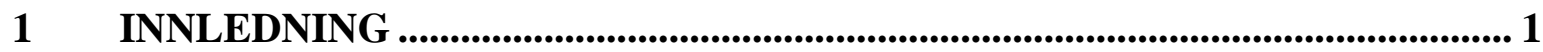

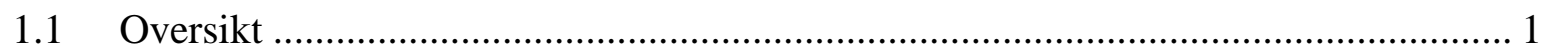

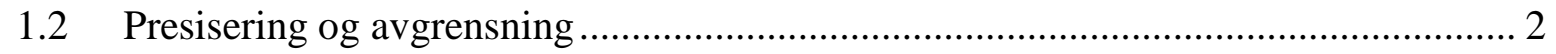

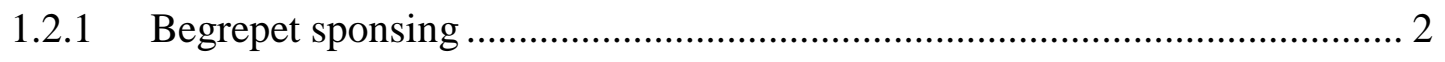

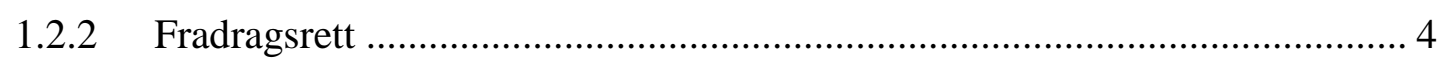

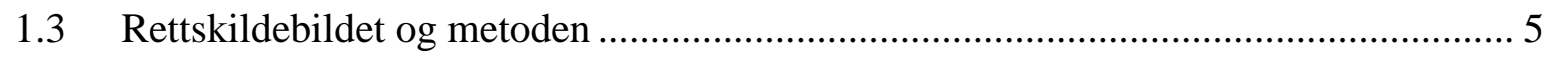

$1.4 \quad$ Videre opplegg ............................................................................................. 7

2 EN OVERSIKT OVER TILKNYTNINGSVILKÅRET........................................ 8

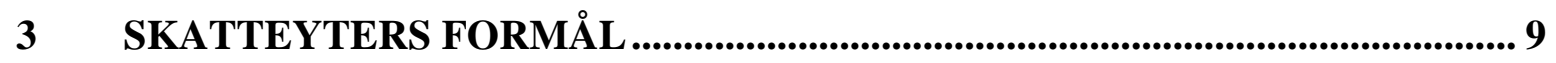

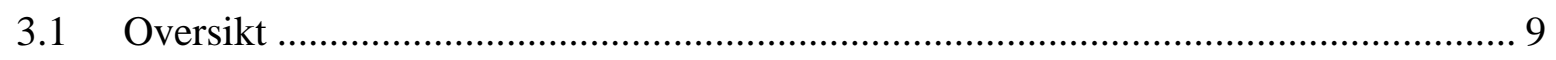

3.2 Formålets rolle i fradragsvurderingen for sponsorutgifter ...................................... 10

3.2.1 To tenkelige formål bak sponsing ............................................................ 11

3.3 Metoden for fastleggelsen av skatteyters formål ....................................................... 12

3.3.1 Innledning .................................................................................. 12

3.3.2 Fastleggelsen av formålet i Skagen-dommen ............................................ 13

3.3.3 Rekkevidden av formålsvurderingen i Skagen-dommen .............................. 18

3.4 Hvilket formål søkes gjennom fastleggelsen? ......................................................... 19

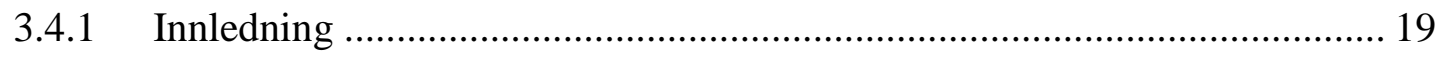

3.4.2 Kommersielle motiver i altruistisk innpakning ........................................... 21

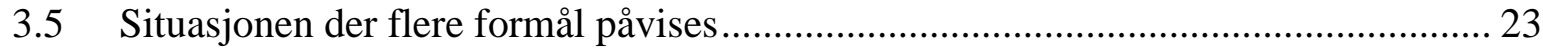

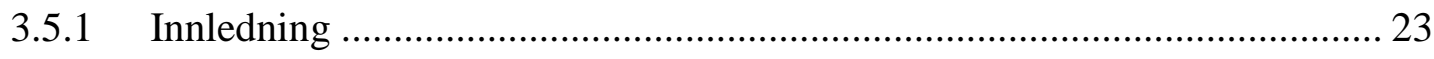

3.5.2 Hovedformålslæren ......................................................................... 24

3.5.3 Forholdsmessig fordeling ................................................................... 26

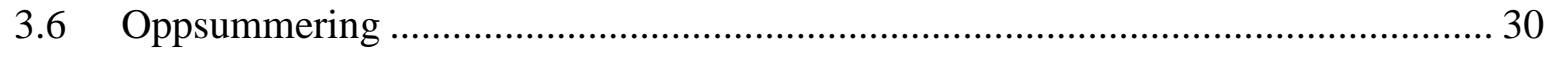


4 KRAVET TIL KOSTNADENS EGNETHET

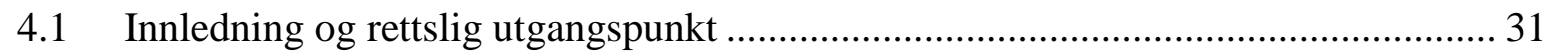

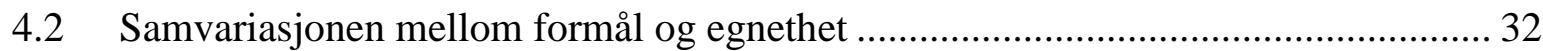

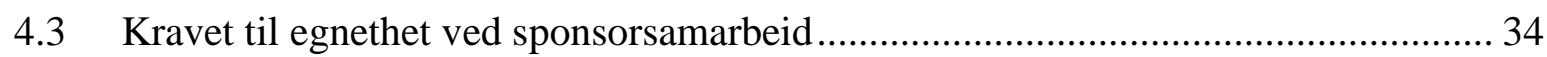

4.4 Betydningen av sponsorobjektet som velges ....................................................... 35

4.5 Sammenhengen mellom sponsor og sponsorobjekt.................................................. 36

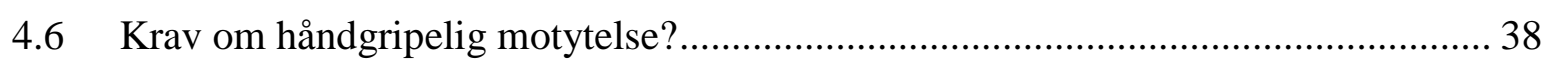

4.6.1 Innledning og rettslig utgangspunkt ............................................................ 38

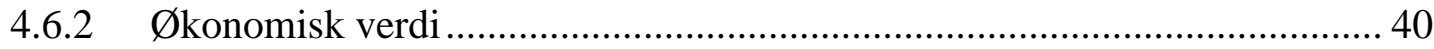

4.6.3 Betydningen av at motytelsen er tilgjengelig for alle ................................. 40

4.6.4 Samvariasjonen mellom formål og motytelser ........................................... 42

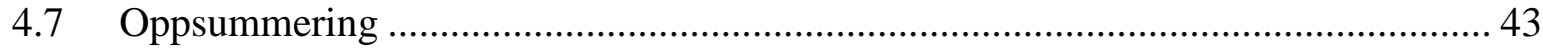

5 ASSOSIASJONSVERDIENS ROLLE I TILKNYTNINGSVURDERINGEN . 44

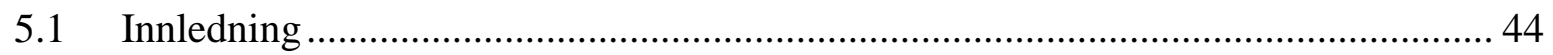

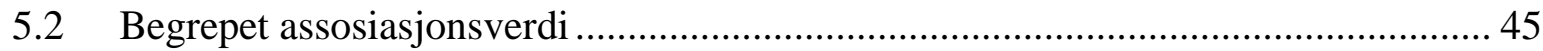

5.3 Rettslige virkninger av assosiasjonsverdien som tilknytningsmoment ..................... 46

6 OPPSUMMERING AV TILKNYTNINGSVURDERINGEN ............................49

7 SPONSING - REPRESENTASJON ELLER GAVE? ..............................................50

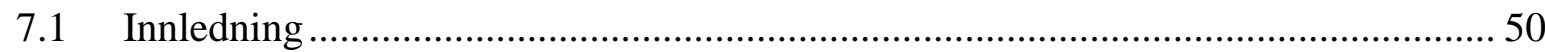

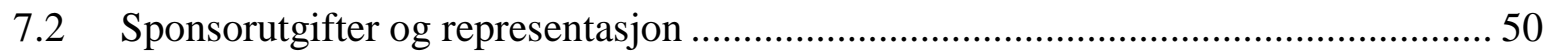

7.3 Sponsorutgifter og gaver til frivillige organisasjoner............................................... 53

8 HENSYNENE BAK FRADRAGSREGLENE I MØTET MED SPONSING.... 55

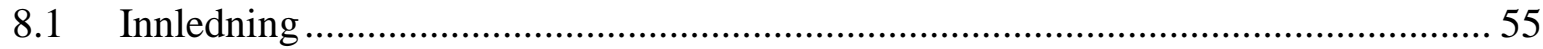

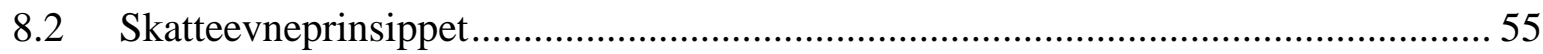

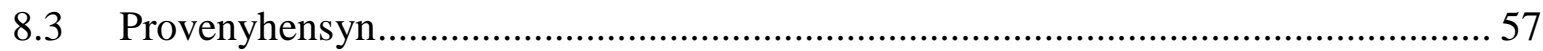

9 REGISTER 


\section{Innledning}

\subsection{Oversikt}

Avhandlingens tema er private bedrifters adgang til å kreve skattemessig inntektsfradrag for utgifter til sponsing. Temaet reiser spørsmål både om hvilke rettsvilkår som må være oppfylt og hvilke faktiske forhold som har betydning for adgangen til å kreve fradrag for sponsorutgifter.

Sponsing har utviklet seg til å bli en viktig del av private virksomheters markedsføringsstrategi. I 2011 brukte norske bedrifter 3805 millioner kroner på sponsing, hvilket utgjorde $15,3 \%$ av de totale reklameinvesteringene i landet. ${ }^{1}$ Dette gjør sponsing til den tredje viktigste markedsføringskanalen etter aviser og TV. ${ }^{2}$ De $\varnothing$ konomiske størrelsene som investeres i sponsing, gjør at adgangen til å kreve fradrag for disse utgiftene har forholdsvis stor $\emptyset$ konomisk betydning, både for statens skatteproveny og den enkelte bedrift som velger sponsing som markedsføringsstrategi.

Samtidig er rettstilstanden rundt adgangen til å kreve skattemessig fradrag for sponsorutgifter uklar. Dette skyldes for det første at norsk skattelovgivning ikke inneholder fradragsbestemmelser som direkte beskriver sponsing. For det andre er rettspraksis på akkurat dette området beskjeden. I mai 2012 avsa Høyesterett en dom der temaet ble behandlet. Høyesterett la imidlertid avgjørende vekt på de konkrete forholdene i saken, slik at fradragsrettens rekkevidde fremdeles langt på vei må anses uavklart på dette området. ${ }^{3}$ For det tredje er det knyttet usikkerhet til hvilke egenskaper sponsing har som markedsføringsmetode, og hvilken sammenheng som foreligger mellom investeringer i sponsing og $\varnothing \mathrm{kt}$ omsetning. ${ }^{4}$ Dette

\footnotetext{
${ }^{1}$ IRM. Norsk Mediestatistikk, 2011. http://www.irm-media.no/arsstatistikk.aspx (referert 14.09.12).

2 Tjømøe, Hans Mathias, 2010: "Sponsing-forretning eller lek med penger". Magma 1 (10). http://www.magma.no/sponsing-forretning-eller-lek-med-penger.

${ }^{3}$ Rt. 2012 s. 744.

${ }^{4}$ Cornwell, Weeks and Roy, 2005: "Sponsorship-linked Marketing: Opening the Black Box". Journal of advertising vol. 34 no. 2 p. 21-42.
} 
gjør det vanskelig for det enkelte selskap å sannsynliggjøre tilstrekkelig tilknytning mellom sponsorutgiftene og skattepliktig inntekt, noe som er et avgjørende vilkår for fradragsrett. ${ }^{5}$

Den utstrakte bruken av sponsing som markedsføringsstrategi sammenholdt med usikkerhet knyttet til vilkårene for fradragsretten gjør temaet aktuelt.

\subsection{Presisering og avgrensning}

Avhandlingen dreier seg om sponsorutgifter og fradragsrett. Begrepene "sponsing" og "sponsorutgifter" er nøkkelbegreper. Som det vil bli gjort rede for, kan begrepenes omfang og innhold være av avgjørende betydning for om vilkårene for fradragsrett er oppfylt. Avhandlingens tema forutsetter derfor en beskrivelse av hva sponsing er, og hvordan begrepet er forstått i avhandlingen.

\subsubsection{Begrepet sponsing}

Det finnes som nevnt ingen legaldefinisjon på sponsing i norsk skattelovgivning. Heller ikke i fagmiljøer for markedsføring har man en enhetlig definisjon av begrepet. ${ }^{6}$ En hyppig brukt definisjon er imidlertid at sponsing er "a business transaction that benefits both the sponsor and the sponsored, and aims to achieve clearly defined goals". 7 Det foreligger også bred enighet om at begrepet sponsing innebærer et økonomisk bidrag som er begrunnet i "kommersielle mål, på lik linje med andre kommunikasjonsverktфy $i$ merkevarebygging". 8

Eksempler kan være der skiløpere eller andre idrettsutøvere mottar penger fra en bedrift, mot at bedriftens logo vises på utøveren under idrettsarrangementet og i forbindelse med

\footnotetext{
${ }^{5}$ Se bla. Rt. 1956 s. 1188 , Rt. 1965 s. 956 og Rt. 2012 s. 744.

${ }^{6}$ John A Meenaghan, 1983: "Commercial Sponsorship". European Journal of Marketing, Vol. 17 Iss: 7 p.5-73.

${ }^{7}$ Victor Head, sitert fra Gran og Hofplass, Kultursponsing, 2007, s. 34.

${ }^{8}$ Skard, Siv, 2011: "Hvordan virker egentlig sponsing?". Magma 4 (11).
} 
TV-intervjuer og lignende. Sponsing kan også være betalinger til en kulturinstitusjon, mot at sponsor får sin virksomhet markedsført mer eller mindre tydelig gjennom logoeksponering i programblader eller medieoppslag. Som et konkret eksempel, inngikk MercedesBenz Norge en avtale med Den norske Opera, hvor Mercedes forpliktet seg til å betale 7 millioner kroner til Den Norske Opera over en periode på tre og et halvt år, mot nærmere definerte markedsføringsrettigheter. ${ }^{9}$

En tredje form for sponsing er såkalt sosiosponsing. Dette er sponsing der en bedrift yter $\varnothing$ konomiske bidrag til en ideell organisasjon mot å bli profilert av, og for å bli assosiert med, den ideelle organisasjonen eller verdiene organisasjonen representerer.

Sponsing kan ut ifra dette beskrives som en form for indirekte reklame der sponsoren yter et $\varnothing$ konomisk bidrag til en person eller organisasjon med antatt evne til å tiltrekke publikums oppmerksomhet. Mottakeren av sponsormidlene reklamerer til gjengjeld for sponsoren ved å eksponere dennes logo under arrangementer eller i situasjoner hvor publikums oppmerksomhet er rettet mot mottaker. Hensikten med sponsingen for sponsoren, er dermed at publikum skal få positive assosiasjoner til sponsoren selv eller dennes produkter. Dette skjer ved at publikum enten får vite direkte at sponsoren har ytet bidraget, eller blir eksponert for sponsorens varemerke i en setting publikum opplever som positiv. Sponsortiltak kan skje både i forbindelse med konkrete idretts- eller kulturarrangementer, eller mer generelt i mottakers kommunikasjon med omverdenen gjennom profilering på hjemmesider, medlemsblader og lignende. ${ }^{10}$

Det har imidlertid vært anført at sponsing også omfatter ytelser fra sponsor begrunnet i ren veldedighet og at dette må skilles fra sponsing av kommersiell karakter. Det skilles i denne sammenheng mellom sosial og kommersiell sponsing, hvor sosial sponsing er motivert av

\footnotetext{
${ }^{9}$ Midsjø, Line, 2007: "Mercedes sponser Operaen". Kampanje. http://www.kampanje.com/markedsforing/article5250637.ece [sitert 10.10.12].

${ }^{10}$ Cornwell, Weeks and Roy, 2005: "Sponsorship-linked Marketing: Opening the Black Box". Journal of advertising vol. 34 no. 2 p. 21-42.
} 
ren veldedighet fra sponsors side. ${ }^{11}$ Oppfatningen om at sponsing også omfatter ren veldedighet har imidlertid blitt kritisert, og det har vært hevdet at alt som kan kalles sponsing, til syvende og sist har kommersielle motiver. ${ }^{12}$

I denne avhandlingen benyttes begrepet sponsing om samarbeid både der motivet er kommersielt, veldedig eller begge deler. En slik vid begrepsbruk anvendes for å fange opp og peke ut hva som er fradragsberettigede sponsorutgifter, og hva som ikke er det. En slik forståelse av sponsorbegrepet ble også anvendt i dommen inntatt i Rt. 2012 s. 744, der samarbeidsavtaler hvor skatteyter ytet bidrag til veldedige organisasjoner ble betegnet som "sponsorat", og skatteyter som "hovedsponsor". ${ }^{13}$ Her ble størstedelen av bidragene ansett for å ha veldedig karakter. Dette taler også for en vid anvendelse av begrepet i denne sammenhengen, hvor det skal foretas en skatterettslig vurdering av sponsing.

\subsubsection{Fradragsrett}

Med fradragsrett menes i avhandlingen adgangen til å kreve skattemessig inntektsfradrag for en kostnad.

Retten til inntektsfradrag må sees i sammenheng med hovedregelen i skatteloven $\S 5-1$ om at enhver fordel vunnet ved arbeid, kapital, eller virksomhet er skattepliktig inntekt. Skatteloven § 6-1 gir samtidig hjemmel for å kreve fradrag i den skattepliktige inntekten, for kostnader som er pådratt for å sikre mv. slik skattepliktig inntekt. Kostnadene som kommer til fradrag reduserer dermed inntekten det skal betales skatt av. Spørsmålet om fradragsrett er av betydning for skatteyter, fordi fradragsretten påvirker hvor stort grunnlaget for beskatning blir. Dette innebærer at dersom det gis fradrag for en kostnad, blir inntekten det skal betales skatt av redusert med samme beløp som kostnaden det gis fradrag for. Til

\footnotetext{
${ }^{11}$ Peggy Simcic Brønn. 2012: "Skal sponsing av sosiale tiltak gi skattefradrag?". Kampanje, 18.6. http://www.kampanje.com/kommentert/article6101802.ece. [Sitert 03.10.12].

${ }^{12}$ Hans Mathias Tjømøe, 2012: "- Hvordan virker sponsing?". Kampanje. 3.7. http://www.kampanje.com/kommentert/article6133800.ece [Sitert 03.10.12]

${ }^{13}$ Se Rt. 2012 s. 744 avs. 47 og 40.
} 
sammen utgjør kommune og fylkeskommuneskatt samt fellesskatt til staten en skattesats på $28 \% .{ }^{14}$ Dette medfører at skatteyter får en besparelse tilsvarende $28 \%$ av den aktuelle kostnaden dersom fradrag gis. Fradragsretten påvirker derfor lønnsomheten i en bedrift.

Spørsmål knyttet til merverdiavgift behandles kun i den utstrekning merverdiavgift utgjør et relevant moment i vurderingen av adgangen til inntektsfradrag. Dette gjøres både av hensyn til avhandlingens omfangsbegrensning, samt hensynet til avhandlingens konkrete fokus på fradrag i inntekt.

\subsection{Rettskildebildet og metoden}

Den skatterettslige adgangen til å kreve inntektsfradrag er regulert i skatteloven kapittel 6 om fradrag i alminnelig inntekt. ${ }^{15}$ Hovedregelen om fradrag fremgår av $§ 6-1$, og suppleres av en rekke bestemmelser som regulerer nærmere angitte fradragskategorier. ${ }^{16}$ Siden det ikke finnes noen fradragsbestemmelse som direkte beskriver sponsing, må hjemmelen for fradragsrett for sponsorutgifter søkes i $\S 6-1$. Bestemmelsen hjemler fradrag for "kostnader” som er "pådratt for å erverve, vedlikeholde eller sikre skattepliktig inntekt". At kostnaden må være "pådratt", betyr at det må foreligge en oppofrelse av en fordel. ${ }^{17}$ Med dette menes at kostnaden må medføre en reduksjon i skatteyters formuesstilling. ${ }^{18}$ For sponsorutgifter vil dette vilkåret normalt være oppfylt. Dette skyldes at utgifter til sponsing som regel innebærer en kontant økonomisk overføring fra skatteyter til mottaker, og at selskapet normalt ikke vil få en motytelse av varig verdi. ${ }^{19}$ Fraværet av motytelser av varig verdi medfører at kostnaden reduserer selskapets formuesstilling når betaling av sponsorutgiftene skjer. Dermed er oppofrelsesvilkåret oppfylt ved betaling av sponsorutgiften.

\footnotetext{
${ }^{14}$ Jf. F24.11.2011 nr. 1151 Stortingsvedtak om skatt av inntekt og formue mv. for inntektsåret 2012 (Stortingets skattevedtak) Kapittel 3.

${ }^{15}$ Lov av 26.03.1999 nr. 14 om skatt av formue og inntekt.

${ }^{16}$ Se bla. sktl. § 6-10 flg.

${ }^{17}$ Zimmer, 2009 s. 174.

${ }^{18}$ Ibid. s. 176.

${ }^{19}$ Se Zimmer, 2009 s. 176 og Cornwell, Weeks and Roy. 2005: "Sponsorship-linked Marketing: Opening the Black Box". Journal of advertising vol. 34 no. 2 s.21-42.
} 
Et rettsvilkår som derimot forutsetter grundig behandling er tilknytningsvilkåret i $\S 6-1$. Etter bestemmelsen må det foreligge en tilstrekkelig tilknytning mellom skatteyters kostnad på den ene siden, og sikring mv. av skattepliktig inntekt på den andre. ${ }^{20}$ Det kreves altså en sammenheng mellom kostnaden det kreves fradrag for, og skatteyters skattepliktige inntekt. I vurderingen av om slik sammenheng foreligger, og dermed om tilknytningsvilkåret er oppfylt, må en rekke momenter hensyntas. Disse momentene omfatter skatteyters formål, kostnadens egnethet, samt hvilken motytelse skatteyter har mottatt i forbindelse med kostnaden. $^{21}$

Et rettslig utgangspunkt er at tilknytningsvilkåret anses oppfylt for skatteyters kostnader til markedsføring av egen virksomhet og egne produkter. ${ }^{22}$ I både retts- og ligningspraksis er standpunktet videre at det for alle typer markedsføring, herunder sponsing, gis fradrag for reklameverdien av markedsføringsutgiftene. Dette har sammenheng med at de utgiftene som tilsvarer reklameverdien betraktes som tilstrekkelig knyttet til skatteyters inntektsskapende virksomhet. Dette gir et utgangspunkt for løsningen på spørsmålet om rekkevidden av fradragsretten for sponsorutgifter. Grunnen til at dette imidlertid kun er et utgangspunkt, er at det kan stilles spørsmål ved om det aktuelle sponsorsamarbeidet i det hele tatt skal vurderes som markedsføring. Dette utgangspunktet gir heller ikke et klart svar på hvor stor del av sponsorutgiften som kommer til fradrag, ettersom reklameverdien av et sponsorsamarbeid kan være omtvistet.

Rettspraksis gir viktige føringer for rekkevidden av fradragsretten. Den ene Høyesterettsdommen som har behandlet fradragsretten for sponsorutgifter danner et naturlig grunnlag for løsningen på spørsmålene avhandlingen reiser. ${ }^{23}$ Dommer som gjelder fradragsrett for

\footnotetext{
${ }^{20}$ Ibid. s. 189.

${ }^{21}$ Ibid. s. 191 flg. samt Aarbakke, 1987 s. avs. 29.6.2.

${ }^{22}$ Se Gjems-Onstad, Norsk Bedriftsskatterett (2001) side 294. og Lignings-ABC 2012 s. 1076.

${ }^{23}$ Se Rt. 2012 s. 744.
} 
andre typer kostnader er imidlertid også relevante. Disse trekkes inn der de kan bidra til avklaring av adgangen til å kreve fradrag.

I en rekke Høyesterettsdommer har ligningspraksis blitt tillagt betydelig vekt. ${ }^{24}$ Ligningspraksis utgjør derfor også en relevant rettskilde i behandlingen av avhandlingens tema.

Som det vil fremgå, kan sponsingens egenskaper og tilknytning til skatteyters inntekt være avgjørende for fradragsretten. Avhandlingens fokus på sponsorutgifter forutsetter derfor en vurdering av sponsingens egenskaper som markedsføringsstrategi, der disse egenskapene kan sies å påvirke retten til fradrag. Det at det foreligger uenighet rundt sponsingens egenskaper og virkninger fordrer en kildekritisk metode som belyser uenigheten i relevante fagmiljøer og skaper en balansert fremstilling av denne formen for markedsføring.

I behandlingen av de rettslige spørsmålene som oppstår rundt fradragsretten, danner alminnelig norsk rettskildelære et naturlig metodisk grunnlag.

\subsection{Videre opplegg}

Det videre opplegget tar sikte på en analyse av både rettskildebildet og sponsingens egenskaper som markedsføringsmetode for å komme frem til hvilke konkrete omstendigheter som har betydning for retten til å kreve fradrag for sponsorutgifter.

I kapittel 2 gis en kort oversikt over tilknytningsvilkåret. I kapittel 3 til 6 behandles ulike kriterier under tilknytningsvilkåret, som er relevante for fradragsretten for sponsorutgifter. Deretter vil jeg i kapittel 7 behandle sponsing i relasjon til skattelovens fradragsbestemmelser om representasjon og gaver ( $\$$ 6-21 og 6-50). Til slutt, i kapittel 8, vurderes fradragsreglenes evne til å ivareta sine formål i møtet med sponsing som markedsføringsstrategi.

\footnotetext{
${ }^{24}$ Se Zimmer, 2009 s. 53.
} 


\section{En oversikt over tilknytningsvilkåret}

Tilknytningsvilkåret har altså en helt sentral rolle i vurderingen av fradragsretten for sponsorutgifter. Det meste av avhandlingen er derfor viet dette vilkåret. Vilkårets sentrale rolle skyldes utfordringene ved å påvise en sammenheng mellom sponsorutgiften og effekten denne har på skatteyters inntekt. Utgifter til reklame kan som nevnt fradragsføres fordi det er forutsatt at sammenhengen mellom kostnaden og skatteyters inntekt er tilstrekkelig. ${ }^{25}$ Det kan imidlertid være en større utfordring å påvise denne sammenhengen ved et sponsorsamarbeid enn ved mer ordinær reklame. Dette skyldes både at sponsing er et mindre tradisjonelt virkemiddel og fordi sponsing kan befinne seg i en gråsone mellom reklame og gave. $^{26}$

Tilknytningsvilkåret er et rettsvilkår som legger opp til en skjønnsmessig vurdering der flere kriterier og momenter er av betydning for om vilkåret er oppfylt. Momentene og kriteriene under tilknytningsvilkåret omfatter skatteyters formål om å $\emptyset$ ke skattepliktig inntekt samt kostnadens egnethet til å skape inntektserverv. I tillegg kommer egne momenter som dukker opp spesielt i relasjon til sponsorutgifter. I de neste fire kapitlene behandles de ulike kriteriene under tilknytningsvilkåret. Først behandles skatteyters formål som tilknytningsvilkår og deretter hvilke krav det kan stilles til utgiftens egnethet. Til slutt reises spørsmålet om i hvilken grad oppnådd assosiasjonsverdi kan bidra til å oppfylle tilknytningsvilkåret.

\footnotetext{
${ }^{25}$ Se for eksempel Rt. 1956 s. 1188.

${ }^{26}$ Se Skar, Liv, 2009: "Sponsing - tid for å åpne den sorte boks". Kampanje 1.
} 


\section{Skatteyters formål}

\subsection{Oversikt}

Et moment i vurderingen av om tilknytningsvilkåret er oppfylt, er altså om formålet med kostnaden er å sikre, erverve eller vedlikeholde skattepliktig inntekt. ${ }^{27}$ Dette kan i første

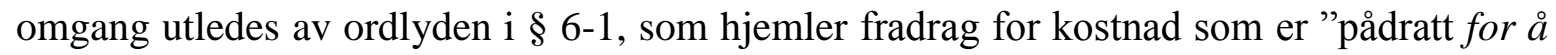
sikre, erverve eller vedlikeholde skattepliktig inntekt".

Skatteyters formål er videre vektlagt i en rekke høyesterettsavgjørelser der spørsmålet er om tilknytningsvilkåret er oppfylt. I dommen inntatt i Rt. 1956 s. 1188 (Anth. B. Nilsen), ble det vurdert om kostnadene til en annonsekampanje skulle regnes som fradragsberettigede reklameutgifter eller ikke-fradragsberettiget politisk agitasjon. I vurderingen av om tilknytningsvilkåret var oppfylt la Høyesterett vekt på at annonsekampanjens formål var å øke omsetningen: "Jeg legger til grunn at formålet med den annonsekampanje ... har vart å fremme firmaets фkonomiske interesser, med andre ord hensynet til "inntekts ervervelse, sikrelse og vedlikeholdelse" ${ }^{\prime \prime}{ }^{28}$ Spørsmålet ble løst etter dagjeldende byskattelov $§ 38$. Dagens bestemmelse i skatteloven $\S 6$-1innebærer imidlertid ingen realitetsendring fra byskattelovens fradragsregel, og rettspraksis fra før skatteloven regnes derfor som relevant. ${ }^{29}$ Dommen viser at formålet kan være nettopp det momentet som skaper en sammenheng tilknytning - mellom kostnaden og inntektservervet.

Skatteyters formål ble videre tillagt vekt i dommen inntatt i Rt. 2009 s. 1467 (Samdal). Saken her dreide seg om en investor som krevde kostnadsfradrag etter å ha blitt utsatt for svindel i forbindelse med et eiendomsprosjekt i Spania. Spørsmålet for Høyesterett var blant annet om det forelå en tilstrekkelig tilknytning mellom de tapte investeringene (kostnaden) og skatteyters inntektserverv. Høyesterett kom til at slik tilknytning forelå, og la vekt på at "Samdal hadde investert i rettar i prosjektet med tanke på videresal og den av-

\footnotetext{
${ }^{27}$ Se Zimmer, 2009 avs. 7.4.2 a.

${ }^{28}$ Rt. 1956 s. 1188 avs. 7.

${ }^{29}$ Se Ot.prp. nr. $861997-98$ s. 13.
} 
kastninga han meinte å få ved dette". Høyesterett kom med dette til at det var "Samdal sin intensjon å skape inntekt", og at det dermed forelå tilstrekkelig tilknytning. ${ }^{30}$ Resonnementet i dommen bygger i stor grad på dommen inntatt i Rt. 2007 s. 1822 (DSC) som også dreier seg om fradragsretten for en kostnad som hadde oppstått ved at skatteyter hadde blitt utsatt for svindel. ${ }^{31}$ I begge dommene er det altså skatteyters motiv bak kostnaden, som blir vurderingskriteriet for om tilknytning foreligger. Det er dermed relevant å se på hva skatteyter søker å oppnå gjennom investeringene som foretas, og i hvilken grad motivet er å fremme skatteyters inntekt.

\subsection{Formålets rolle $\mathrm{i}$ fradragsvurderingen for sponsorutgifter}

Spørsmålet er deretter hvordan skatteyters formål spiller inn når fradragsretten for sponsorutgifter skal vurderes. Også i Høyesteretts dom i saken mellom Skagen og Skatt vest spilte formålet en sentral rolle i tilknytningsvurderingen. ${ }^{32}$ I denne saken var spørsmålet hvorvidt Skagen kunne kreve fradrag for kostnader finansforetaket hadde hatt $\mathrm{i}$ forbindelse med samarbeidsprosjekter med de to ideelle organisasjonene SOS-barnebyer og CARF. Skagen hadde forpliktet seg til å betale til sammen 11,2 millioner kroner gjennom samarbeidet. Hovedspørsmålet i saken var om tilknytningsvilkåret var oppfylt for alle disse kostnadene. Skatt vest mente at størstedelen av sponsorutgiftene måtte anses som gaver, og at de derfor ikke hadde tilstrekkelig tilknytning til Skagens inntektserverv. I vurderingen av tilknytningsvilkåret uttalte Høyesterett at "ved avgjørelsen av om tilknytningsvilkåret er oppfylt, vil skatteyters formål med kostnaden vare et relevant moment... ${ }^{33}$ Skagens formål med prosjektene ble deretter behandlet grundig som et viktig ledd i avgjørelsen av om tilknytningsvilkåret var oppfylt. ${ }^{34}$ I relasjon til sponsing kan det spørres om hvilke formål som utpeker seg som aktuelle i vurderingen, og hvordan disse formålene presumptivt påvirker fradragsretten.

\footnotetext{
${ }^{30}$ Se Rt. 2009 s. 1467 avs. 34.

${ }^{31}$ Se Rt. 2007 s. 1822 avs. 50.

${ }^{32}$ Rt. 2012 s. 744.

${ }^{33}$ Ibid. avs. 45.

${ }^{34}$ Ibid. avs. 47-50.
} 


\subsubsection{To tenkelige formål bak sponsing}

Selv om formålet bak en sponsoravtale må vurderes konkret, er det presumptivt to ulike hovedformål som kan tenkes når fradragsretten skal vurderes. Det ene er at motivet bak investeringen er å markedsføre egen virksomhet for å øke omsetningen. Det andre formålet som kan tenkes, er at man ønsker å berike mottakeren av sponsormidlene uten noe krav om motytelse, altså at motivet er å gi en gave.

Dersom formålet med sponsorsamarbeidet er å markedsføre egen virksomhet, og dermed $\emptyset$ ke omsetningen, taler dette for at tilknytningsvilkåret er oppfylt. Dette skyldes at det dermed foreligger en tiltenkt sammenheng mellom sponsorutgiftene og sponsors inntekt. Som nevnt i avsnitt 1.3., regnes utgifter til markedsføring og reklame som fradragsberettigete driftskostnader. ${ }^{35}$

Hvis formålet bak sponsorutgiftene derimot kun er å berike mottaker, tilsier dette at det ikke er en tilstrekkelig tilknytning mellom skatteyters kostnad og inntektservervelse. Dette kommer av at en gave i skatteretten betegnes som en frivillig overføring av verdier uten

motytelse. ${ }^{36}$ Formålet bak en gave er dermed presumptivt ikke å $\emptyset$ ke omsetningen, ettersom det ikke foreligger noen motytelse som kan bidra positivt på skatteyters inntekt. Uten et formål om å $ø$ ke omsetningen eller påvirke inntekten positivt på annen måte, kan man dermed gå ut ifra at det ikke foreligger en tilknytning mellom kostnad og inntekt. Dette var et helt sentralt moment i Skagen-dommen ved at størstedelen av Skagens ytelser etter sponsoravtalen ble ansett å ha som formål å berike mottaker. Ytelsene hadde dermed ikke tilstrekkelig tilknytning til Skagens inntektservervelse og fradrag ble således nektet.

\footnotetext{
${ }^{35}$ Se Gjems-Onstad, 2001, Norsk Bedriftsskatterett side 294. og Lignings-ABC 2012 s. 1076.

${ }^{36}$ Se Lignings-ABC 2012 s. 682 jf. Rt. 2012 s. 744 avs. 52.
} 


\subsection{Metoden for fastleggelsen av skatteyters formål}

\subsubsection{Innledning}

At formålet med kostnaden er relevant i relasjon til tilknytningsvilkåret både generelt og i vurderingen av sponsorutgifter, er nå brakt på det rene. Det neste spørsmålet er hvordan rettsanvender går fram for å konstatere skatteyters formål bak kostnaden. Vi beveger oss dermed inn på metodikken som legges til grunn for å fastslå sponsors intensjoner bak kostnadene det kreves fradrag for. Selve metoden for fastleggelsen av skatteyters formål, herunder hvilke momenter som vektlegges, kan være avgjørende for adgangen til å kreve fradrag. Spørsmål som melder seg i denne sammenheng er hvilket tidspunkt som skal legges til grunn for vurderingen av formålet og hvilke kriterier og hensyn som anvendes når formålet skal konstateres.

\subsubsection{Tidspunktet for bedømmelsen}

Når skatteyters formål skal fastlegges, er det tidspunktet for da vedkommende forpliktet seg til å bære kostnaden, som legges til grunn. Dette er blant annet konstatert i Samdaldommen, hvor Høyesterett uttaler at det ved vurderingen av kostnaden må "takast utgangspunkt i situasjonen slik denne var på investeringstidspunktet". ${ }^{37}$ For utgifter til sponsing, innebærer dette at vurderingen av fradragsretten må ta utgangspunkt $\mathrm{i}$ tidspunktet for da sponsor pådro seg kostnadene etter sponsoravtalen. Dersom motivet lå i å øke omsetningen og dermed den skattepliktige inntekten på dette tidspunktet, er dette et moment som taler for at fradragsrett foreligger.

\subsubsection{Objektive kjensgjerninger}

Når skatteyters formål skal påvises, er det ikke vedkommendes rent subjektive tankeprosesser som er avgjørende. I Anth. B. Nilsen kom dette frem ved at man i vurderingen av skatteyters formål uttalte: "Spørsmålet om fradragsrett for de omtvistede annonseutgiftene

\footnotetext{
${ }^{37}$ Se Rt. 2009 s. 1473 avs. 37, nederst.
} 
kan nemlig etter mitt skjфnn ikke avgjфres utelukkende på subjektivt grunnlag ${ }^{\prime 2}{ }^{38}$ Fastleggelsen av formålet bak kostnaden skal skje ut ifra en objektivisering av skatteyters subjektive motiver. ${ }^{39}$ I Samdal-dommen blir det uttalt at "Som tingretten skriv, tilseier dei objektive kjensgjerningane rundt investeringa at det var Samdal sin intensjon å skape inntekt". ${ }^{40}$ Høyesterett legger altså vekt på de objektive kjensgjerningene rundt forholdet for å fastlegge skatteyters formål. Hvilke konkrete kjensgjerninger det dreier seg om, går imidlertid ikke Høyesterett inn på. Det henvises her til tingrettens vurdering, men tingrettsdommen er taus om hvilke objektive kjensgjerninger retten la vekt på, og hvordan retten kom frem til formålet. $^{41}$

At man legger vekt på ytre, objektivt konstaterbare momenter, gjør det enklere for skattemyndigheter og domstoler å påvise skatteyters formål. Å basere seg på skatteyters rent subjektive uttalelser vil kunne gi et misvisende bilde, farget av skatteyters ønske om å få fradrag for den aktuelle kostnaden. I tillegg kan skatteyters subjektive uttalelser om formålet endre seg med tiden, slik at man ikke får konstatert formålet slik det fremsto da kostnaden ble pådratt. Ved vurderingen av ytre, objektive kjennetegn, har man et håndfast bevis for hva formålet var på tidspunktet da kostnaden ble pådratt.

I relasjon til retten til fradrag for sponsorutgifter er det etter dette relevant å gå nærmere inn på de enkelte momenter skattemyndigheter og domstoler erfaringsvis legger vekt på når formålet bak en kostnad skal fastlegges.

\subsubsection{Fastleggelsen av formålet i Skagen-dommen}

I Skagen-dommen skjer fastleggelsen av skatteyters formål gjennom en inngående behandling av de konkrete ytre omstendighetene i saken. Høyesterett henviser til Samdal-dommen

\footnotetext{
${ }^{38}$ Se Rt. 1956 s. 1188 , på s. 1189.

${ }^{39}$ Zimmer, 2009 s. 192.

${ }^{40}$ Rt. 2009 s. 1467 avs. 34.

${ }^{41}$ Se Utv. 2008 s. 1278.
} 
og påpeker at det er de "objektive kjensgjerningane" i saken som er relevante i fastleggelsen av skatteyters formål. Videre blir det uttalt at "Som jeg har redegjort for, er Skagens formål med sponsoratet slik dette fremstår ut fra de ytre, objektive kjennetegn i saken et relevant moment". ${ }^{42}$ Den objektive tilnærmingen som følger av tidligere rettspraksis, følges dermed opp i Skagen-dommen. Videre fastlegger Høyesterett Skagens formål gjennom en fortolkning av begrepsbruken partene hadde valgt i avtaler, fakturering, årsrapporter, medieomtale og annen ekstern kommunikasjon. ${ }^{43}$ I det følgende behandles hvordan disse momentene påvirker fradragsspørsmålet.

\subsubsection{Det formelle avtaleverket}

I Høyesteretts vurdering av de formelle avtalene, blir det lagt vekt på at Skagen ga uttrykk for at de ønsket å yte "finansiell støtte" til samarbeidspartnerne. Høyesterett tolker dette slik at "Begrepet "støtte" indikerer at Skagens formål først og fremst har vart å berike organisasjonene". Avtalepartenes valg av ordlyd i denne delen av avtalen blir vektlagt for å komme frem til Skagens formål, slik det skal legges til grunn i den skatterettslige vurderingen av fradragsspørsmålet. Høyesteretts fortolkning av begrepet "støtte" blir dermed en viktig faktor i vurderingen av skatteyters formål, og dermed om tilknytningsvilkåret er oppfylt.

Dette er ikke første gang Høyesterett bruker en fortolkning av partenes avtaledokumenter for å fastlegge skatteyters formål. Det samme ble gjort i dommen inntatt i Rt. 1965 s. 954 (Kosmos). Saken omhandlet et selskap som hadde bidratt til finansieringen av et hotellbygg med representasjons- og kontorlokaler i Sandefjord. Byen hadde ikke et passende hotell for konferanse- og møtevirksomhet, og Kosmos hadde behov for dette i nærheten av sin virksomhet $\mathrm{i}$ byen. Byggingen av hotellet ble mer kostbart enn forventet, og Kosmos krevde fradrag for en del av tapet som oppsto i den sammenheng. En viktig del av vurderingen av tilknytningsvilkåret, var om formålet med oppføringen av bygningen var å styrke skatte-

\footnotetext{
${ }^{42}$ Se Rt. 2012 s. 744 avs. 47.

${ }^{43}$ Ibid. avs. 47-53.
} 
yters inntektserverv. I fastleggelsen av formålet gikk man også her konkret inn i skatteyters formelle avtale for å komme frem til formålet:

"Jeg peker i denne sammenheng på at det i interesseavtalens punkt 1 var bestemt at interessentskapet hadde til formål å bygge "Hvalfangstens hus" for "å dekke det behov hvalfangsten og det фvrige naringsliv i byen og distriktet har for et slikt hus". ${ }^{4}$

Dette styrker Skagen-dommens vekt når det gjelder fremgangsmåten for konstateringen av skatteyters formål.

Selv om fokuset på formelle avtaler ikke er noe nytt som dukket opp i Skagen, kan det hevdes at Skagen-dommen tar tilnærmingen et skritt videre ved å foreta en konkret ordlyds-

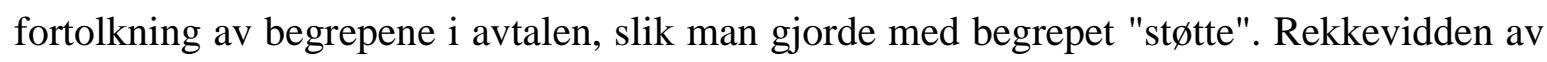
Skagen-dommen på dette området påvirkes imidlertid av at man hadde begreper $\mathrm{i}$ avtalen som nettopp antydet noe om formålet. Skagen-dommen bekrefter uansett at skatteyters formuleringer i avtalebestemmelser utgjør et relevant moment i fastleggelsen av skatteyters formål.

\subsubsection{Ekstern kommunikasjon og omtale}

I påvisningen av hvilke motiver skatteyter hadde bak sponsingen i Skagen-dommen, la Høyesterett i tillegg vekt på hvordan formålet bak sponsingen ble fremstilt i ekstern kommunikasjon, herunder hvordan formålet hadde blitt presentert av partene i media. Det ble i denne sammenheng uttalt: "At Skagen har ment å berike mottakerne stфttes av at begge parter i eksterne kommunikasjonskanaler som presse og årsberetning har omtalt bidragene til SOS-barnebyer som gaver". ${ }^{45}$ Det er dermed ikke bare relevant å vurdere skatteyters egne oppfatninger av sponsorsamarbeidet, men også hvordan formålet oppfattes av omverdenen.

\footnotetext{
${ }^{44}$ Se Rt. 1965 s. 954, avs. 10.

${ }^{45}$ Se Rt. 2012 s. 744, avs. 52.
} 
Vektleggingen av hvordan investeringen fremstår utad, er heller ikke et nytt fenomen i rettspraksis. Dette momentet ble også berørt i Anth. B. Nilsen. Her ble det blant annet lagt vekt på hvordan annonsene "av almenheten så vel som sarlig av de kretser innen naringslivet som firmaet vanligvis henvender seg til, naturlig måtte oppfattes...". ${ }^{46}$ Momentet ble vektlagt i vurderingen av om formålet med annonsekampanjen var reklame eller politisk agitasjon. Høyesteretts vekting av eksterne oppfatninger understrekes videre ved at det om fremstillingen av annonsene uttalles:

"Det foreligger imidlertid ikke holdepunkter for at dette har vart oppfatningen, $i$ hvert fall ikke når det gjelder naringsdrivende i bransjen, - og det er så vidt skjønnes deres mening som i denne forbindelse har avgjфrende betydning".

Den oppfatning omverdenen, og særlig aktører med en relasjon til skatteyter hadde til markedsføringen, var altså et moment i formålsvurderingen.

Vektleggingen av kostnadens fremstilling utad i de to sakene gir grunn til å regne med at dette også vil bli gjort i andre saker der fradragsretten for sponsorutgifter settes på prøve. En viss støtte for dette finner man også i ligningspraksis. I flere saker for Klagenemnda for oljeskatt, har man i vurderingen av fradragsretten for sponsorutgifter lagt vekt på om sponsingen, i ekstern kommunikasjon, er fremstilt som en gave eller som markedsføring. ${ }^{47}$

At skatteyter har et bevisst forhold til hvordan markedsføringen og/eller sponsingen fremstår utad, ligger i tiltakets natur. Hele poenget med sponsorsamarbeid er nettopp hvordan de fremstår overfor, og oppfattes av publikum. Dette er helt avgjørende for effekten av markedsføringstiltaket. Om sponsor er like bevisst på de skattemessige konsekvensene av fremstillingen utad, er imidlertid mindre selvsagt.

\footnotetext{
${ }^{46}$ Se Rt. 1956 s. 1188 , på s. 1190.

${ }^{47}$ Se Klagenemnda for oljeskatt, Kjennelse av 25.2.2002: "Fradrag for bidrag til Stavanger Domkirke", og kjennelse av 25.2.2002: "Fradrag for utgifter til reklame /sponsorvirksomhet /gaver".
} 


\subsubsection{Fakturering og avgiftsmessig håndtering}

Et tredje ytre kjennetegn, som ble vektlagt i fastleggelsen av skatteyters formål i Skagendommen, var hvordan ytelsene hadde blitt kategorisert i faktureringen og den avgiftsmessige behandlingen av ytelsene. Skagen hadde ved faktureringen delt sine ytelser i "prosjektbidrag" og "markedsførings- og eksponeringsrettigheter". I vurderingen av fakturaene som et objektivt kjennetegn på skatteyters formål ble det uttalt: "Ved faktureringen er det altså foretatt begrepsmessige presiseringer som språklig sett bekrefter at Skagen dels vil berike mottakerne...". ${ }^{48}$ De konkrete språklige begrepsvalgene man hadde tatt ved faktureringen tillegges her vekt i vurderingen av hvilket formål skatteyter hadde bak samarbeid og investering.

Oppdelingen i to forskjellige typer ytelser dannet også grunnlag for avgiftshåndteringen av ytelsene. Det var kun beregnet merverdiavgift av det som ble kalt "markedsførings- og eksponeringsrettigheter". Etter merverdiavgiftsloven skal det betales merverdiavgift for "omsetning av varer og tjenester", jf. merverdiavgiftsloven § 3-1. Begrepet "omsetning" innebærer bl.a. "levering av varer og tjenester mot vederlag" jf. § 1-3 1. ledd, bokstav a. Det skal dermed ikke beregnes merverdiavgift på gaver, ettersom en gave forutsetter at det ikke foreligger en motytelse. ${ }^{49}$ Det at det ikke var beregnet merverdiavgift for posten "prosjektbidrag", styrket dermed formodningen om at denne delen var en gave til de ideelle organisasjonene og at tilknytningsvilkåret på grunn av dette ikke var oppfylt.

Avgiftshåndteringen i Skagen fremstår som et tydelig ytre kjennetegn på at formålet med den omstridte delen av sponsorutgiften var en gave. Dersom Skagen $ø$ nsket at alle beløp skulle anses som betaling for markedsføringstjenester, fremstår en slik inndeling som unaturlig. Hva Skagen subjektivt ønsket å oppnå med "prosjektstøtten" er imidlertid ikke nødvendigvis brakt på det rene gjennom vurderingen av avgiftsberegningen og andre ytre kjennetegn.

\footnotetext{
${ }^{48}$ Rt. 2012 s. 744 avs. 50.

${ }^{49}$ Se Lignings-ABC 2012 s. 680, jf. Rt. 2012 s. 744, avs. 52.
} 


\subsubsection{Rekkevidden av formålsvurderingen i Skagen-dommen}

Et spørsmål er hvorfor Høyesterett går så konkret inn i partenes dokumenter og eksterne kommunikasjon i Skagen-dommen, når dette ikke har blitt gjort i nyere rettspraksis, herunder særlig i dommene DSC og Samdal. Dette spørsmålet er relevant fordi det kan fortelle noe om hvilken rekkevidde den konkrete tilnærmingen i Skagen har i fremtidige saker. Dersom det nettopp var de konkrete forholdene i Skagen i seg selv, som medførte tilnærmingen, tilsier dette en mindre generell rekkevidde. Dersom dette derimot utgjør en endring i Høyesteretts generelle tilnærmingsmetode for denne typen fradragsspørsmål, tilsier dette at dommens rekkevidde er større.

\subsubsection{Sakens egenart}

En mulig forklaring på Høyesteretts sterke fokus på ytre kjennetegn, kan være at formålet var så avgjørende for tilknytningsvurderingen i denne saken. Det ser ut til at spørsmålet om formålet skulle betraktes som veldedig eller kommersielt, var et helt sentralt moment for utfallet i saken. I Samdal og DSC, ble ikke formålet satt på spissen på samme måte. For eksempel kunne det betegnes som en kjensgjerning at Samdal, gjennom sine investeringer i et boligprosjekt, hadde til formål å tjene penger og dermed "sikre, erverve eller vedlikeholde skattepliktig inntekt" jf. sktl. § 6-1. ${ }^{50}$ Det ble ikke foretatt noen nærmere vurdering av om dette var formålet. Men dette kan nettopp skyldes at formålet om å tjene penger ligger i en slik investerings natur. I Skagen-dommen vurderer ikke Høyesterett formålet som like entydig og opplagt. Dette kan komme av at kostnaden her relaterte seg til sponsing av ideelle organisasjoner, noe som ikke like tydelig fremstår som kommersielt motivert.

I saker hvor det er uklarhet rundt formålet, og formålet samtidig fremstår som så avgjørende, taler dette for at fremgangsmåten anvendt i Skagen blir videreført i lignende saker. Det-

\footnotetext{
${ }^{50}$ Se Rt. 2009 s. 1473 , avs. 34.
} 
te synet har støtte i Kosmos-dommen. En viktig del av vurderingen av tilknytningsvilkåret i saken, var om formålet med oppføringen av bygningen var å styrke skatteyters inntektserverv. Som nevnt gikk man også her inn på formelle avtaledokumenter for å konstatere formålet. Dette styrker formodningen om at et uklart formål medfører en mer grundig og konkret tilnærming for å konstatere formålet.

\subsubsection{Objektive kjensgjerninger og objektive kjennetegn}

En annen begrunnelse bak Høyesteretts konkrete tilnærming i Skagen, kan være at Høyesterett benytter begrepet "ytre, objektive kjennetegn" på samme måte som vurderingskriteriet "objektive kjensgjerninger" fra Samdal. ${ }^{51} \mathrm{Ut}$ fra en naturlig språklig forståelse av begrepene "kjensgjerning" og "kjennetegn" foreligger det en nyanseforskjell mellom begrepene. Forskjellen består i at det kreves en mindre grad av konstaterbarhet for å kalle noe et kjennetegn enn en kjensgjerning. Kjennetegnsbegrepet kan oppfattes som noe mer vidtrekkende, og derfor som en åpning for å trekke inn flere og andre momenter enn hva "kjensgjerning"-begrepet åpner for.

Det er ikke mulig å lese ut fra premissene om Høyesteretts veksling mellom begrepene i Skagen er bevisst, eller om den er ment å innebære noen endring i fremgangsmåten for å fastlegge skatteyters formål. Uavhengig av dette, fremstår nyanseforskjellen mellom begrepene som såpass liten at den vanskelig kan sies å innebære noen grad av retningsskifte.

\subsection{Hvilket formål søkes gjennom fastleggelsen?}

\subsubsection{Innledning}

Det neste spørsmålet som reises i relasjon til formålet, er om Høyesterett søker å komme frem til skatteyters reelle motiver bak kostnaden, eller om man alene søker å komme frem

\footnotetext{
${ }^{51}$ Se Rt. 2012 s. 744 avs. 47.
} 
til hvordan kostnaden fremstår utad. Som det vil fremgå, er en sponsor nemlig ikke alltid interessert $\mathrm{i}$ å vise omverdenen at sponsorsamarbeidet er kommersielt motivert.

I Skagen-dommen anfører Skagen at statens oppfatning av formålet med sponsorsamarbeidet bygger på en gal forståelse av avtaleverket. ${ }^{52}$ Det anføres i denne sammenheng at kravene om motytelser ikke kunne påvises gjennom en konkret fortolkning av avtalebestemmelsene alene, fordi disse også fulgte mer indirekte av avtalene. ${ }^{53}$

Høyesterett fokuserte altså på ytre kjennetegn til fordel for en vurdering av hva Skagen subjektivt søkte å oppnå gjennom samarbeidet. Som nevnt i avsnitt 3.3.2, gikk man bl.a. inn i en ordlydsfortolkning av begrepet "støtte" i avtalen for å finne Skagens formål bak samarbeidet. Man gikk imidlertid ikke inn på avtalens mer generelle bestemmelser om partenes plikter gjennom samarbeidet, som kunne tilsi at samarbeidet var motivert ut ifra kommersielle hensyn. For eksempel var det avtalt at de ideelle organisasjonene forpliktet seg til "å arbeide aktivt for å fremme Skagens interesser". ${ }^{54}$ Denne bestemmelsen hadde ikke det samme ytre, konkrete skinn av å være ikke-kommersielt motivert. Derimot kunne bestemmelsen si noe om hva Skagen oppriktig ønsket å oppnå gjennom samarbeidet, nemlig å tjene sine egne, kommersielle interesser. Dette forholdet aktualiserer spørsmålet om det er skatteyters reelle formål, eller formålet slik det fremstår utad, som søkes i vurderingen av fradragsretten.

Dersom vektleggingen av objektive kjensgjerninger er en slags bevisregel der det subjektive motivet er underordnet og det avgjørende er hvordan motivet oppfattes eksternt, fremstår vektleggingen av ytre kjennetegn som egnet. Dersom det reelle målet med formålsvurderingen derimot er å komme frem til hva skattesubjektet oppriktig har ment, kan formelle avtaler, og særlig ekstern kommunikasjon, være utilstrekkelig for å nå dette målet. Dette kommer av at skatteyter av forretningsmessige årsaker bevisst kan ha latt sine motiver utad

\footnotetext{
${ }^{52}$ Se Rt. 2012 s. 744 avs. 54-55.

${ }^{53}$ Ibid. avs. 24.

${ }^{54}$ Se Utv. 2010 s. 1434. Stavanger Tingrett. Avs. 67.
} 
fremstå som mindre kommersielle enn de egentlig er. Et fokus utelukkende på eksterne kjennetegn kan dermed tilsi at en tilstrekkelig tilknytning mellom kostnad og inntekt ikke foreligger, imens kostnaden i realiteten er kommersielt motivert. Dette forutsetter en nærmere redegjørelse.

\subsubsection{Kommersielle motiver i altruistisk innpakning}

I vurderingen av formålet bak en sponsoravtale kan et fokus på ekstern kommunikasjon fremstå som uegnet, dersom man ønsker å komme frem til skatteyters reelle motiver. Dette har sammenheng med sponsingens natur som markedsføringsstrategi. Et hovedpoeng fra sponsorens side kan nemlig være å fremstå som velgjører og ikke som profitør, ettersom dette kan ha en bedre markedsføringsmessig effekt. ${ }^{55}$ Det er vanskelig å lese ut av premissene i Skagen-dommen hvor stor vekt man la på omtalen av den aktuelle sponsoravtalen i media, i fastleggelsen av formålet bak sponsorsamarbeidet. Det er imidlertid mye som tyder på at momentet ble brukt for å påvise at Skagens formål med sponsorsamarbeidet var å gi en gave. Dersom hensikten er å komme frem til sponsors reelle motiv bak sponsingen, kan sponsorens eksterne kommunikasjon og pressedekning utgjøre en upålitelig kilde. Dette skyldes at velgjører-rollen kan være en viktig faktor når man vil nå frem til publikum gjennom markedsføringen.

For eksempel vil publikum kunne være mer mottakelig for et budskap når det fremsettes på en måte som gjør at publikum ikke umiddelbart forstår at motivet er kommersielt. Enkelte forskere mener at publikum er mer mottakelig for kommersielle budskap som presenteres gjennom sponsing enn gjennom reklame på TV. ${ }^{56}$ Dette betyr selvfølgelig ikke at det nødvendigvis er slik. Med henblikk på den økonomiske størrelsen av sponsormarkedet, er det imidlertid tydelig at flere virksomheter har tro på sponsing som en effektiv markedsføringsmetode.

\footnotetext{
55 Björn Walliser, 2003: “An International Review Of Sponsorship Research: Extension and Update". International Journal of Advertising, 2003. Vol. 22, No1. s. 3.

${ }^{56}$ Sveriges Annonsörer/Novus, 2012: "Klovna Känslor - Svenskarnas inställning til reklam".
} 
Hvis skatteyter, gjennom skattemyndigheter og domstolers fokus på ytre kjennetegn, tvinges til å bringe sine reelle motiver ut i lyset, påvirker dette hvor attraktivt sponsing er som markedsføringsstrategi. Dette skyldes at effekten av sponsing antas å bli redusert dersom de kommersielle motivene overkommuniseres. Skatteyter står i slike tilfeller tilsynelatende mellom to valg: Å skilte sine motiver for å øke mulighetene for fradrag, eller å skjule de for å oppnå maksimal effekt av markedstiltaket, men til en dyrere pris ved at man ikke får fradrag. Det er mye som taler for at ligningsmyndigheter og domstoler burde erkjenne dilemmaet skatteyter møter gjennom kravet om å skilte sine motiver for omverdenen. En løsning kunne være å forlate fokuset på hvordan sponsoravtalen fremsto i media, og heller kun fokusere på om det forelå tydelig avtalefestede motytelser mellom skatteyter og sponsorobjekt. Da ville man kunne påvise et kommersielt motiv, uten å skade markedsføringstiltaket. Som det vil fremgå av kapittel 4, er det imidlertid ikke gitt at formålet alene etablerer den nødvendige tilknytningen som kreves for å få fradrag. Selv om formålet utad fremstår som kommersielt, medfører ikke dette at tilknytningsvilkåret dermed automatisk er oppfylt.

Det kan spørres om sponsing der kommersielle motiver skjules, og hvor sponsor forsøker å fremstå som en velgjører i samfunnet, skaper et etisk dilemma for skattemyndigheter og domstoler. Ved å tillate fradrag for kostnadene til denne formen for sponsing, kan dette oppfattes som en offentlig godkjenning og velsignelse av en markedsføring som lurer publikum. Synspunktet er at offentlige myndigheter dermed bidrar til tiltak som får publikum til å tro at sponsorbedriftene er velgjørere, samtidig som de i realiteten er kommersielle profittjegere. Avhandlingens rettslige karakter og begrensede omfang medfører imidlertid at dette spørsmålet ikke kan forfølges videre.

Et spørsmål som imidlertid kan forfølges, er om det foreligger et motsetningsforhold mellom formålet om å gi en gave, og et formål om å øke omsetningen. I Skagen-dommen kan det synes som om dette er oppfatningen. Høyesterett uttaler at "Det er etter min oppfatning 
ikke anført noe som rokker ved de objektive kjensgjerninger, nemlig at formålet med prosjektbidragene har vart å berike mottaker" ${ }^{57}$ Det ser deretter ut som at et formål om å berike mottaker utelukker at formålet samtidig kan være $ø$ kt omsetning. Bakgrunnen for oppfatningen ser ut til å være at det ved gaver ikke foreligger noen motytelse som kan bidra til å $\varnothing$ ke skatteyters inntekt. Det kan etter dette se ut til at det ikke nødvendigvis er formålet som er avgjørende i avgjørelsen om det dreier seg om gave, men motytelsen som er avtalt. Dette harmonerer i så fall med den skatterettslige definisjonen av gaver, som en "frivillig overføring av verdier uten motytelse" ${ }^{58}$ Dersom Høyesterett i realiteten vurderer motytelsen som det sentrale i fradragsvurderingen, påvirker dette formålets vekt i fradragsvurderingen. Motytelsenes rolle i fradragsvurderingen behandles i kapittel 4.6.

\subsection{Situasjonen der flere formål påvises}

\subsubsection{Innledning}

Det er nå gjort rede for at skatteyters formål bak sponsorsamarbeidet er helt sentralt for fradragsretten for utgifter til sponsing. Videre er det redegjort for hvordan formålet konstateres ved at man fokuserer på objektive kjennetegn. I Skagen-dommen kom man til at formålet bak de omstridte midlene var å berike de ideelle organisasjonene, altså at det var ett formål bak de delene av kostnadene som var betegnet som "prosjektstøtte". ${ }^{59}$ I prosessen med å fastlegge skatteyters formål kan man imidlertid komme frem til at motivene bak samarbeidet er delte - at det foreligger flere formål bak samme kostnad. Denne situasjonen er særlig aktuell for kostnader til sponsing, ettersom sponsingens egenskaper som markedsføringsstrategi gjør at formålet både kan fremstå som, og faktisk være, delt. Spørsmålet som behandles i dette kapittelet er hvordan denne situasjonen skal løses når fradragsretten vurderes. Situasjonen som behandles, er der èn og samme kostnad både kan sies å ha kommersielle og ikke-kommersielle formål bak seg.

\footnotetext{
${ }^{57}$ Se Rt. 2012 s. 744 , avs. 56.

${ }^{58}$ Se Lignings-ABC 2012 s. 680.

${ }^{59}$ Se Rt. 2012 s. 744 , avs. 56.
} 
I rettspraksis har denne situasjonen blitt løst på to ulike måter, avhengig av hvor enkelt det har vært å knytte hvert enkelt formål til en konkret del eller verdi av kostnaden. Den ene måten har vært anvendelsen av den såkalte hovedformålslæren. Den andre måten har vært å foreta en forholdsmessig fordeling av fradragsberettiget og ikke-fradragsberettiget del av kostnaden. ${ }^{60}$

\subsubsection{Hovedformålslæren}

Hovedformålslæren går ut på å forsøke å identifisere hovedformålet bak kostnaden, og la dette formålet være avgjørende for vurderingen av hele kostnaden. ${ }^{61}$ Spørsmålet som reises i det følgende er hvilke konsekvenser det har for fradragsretten for sponsorutgifter at hovedformålslæren kommer til anvendelse.

\subsubsection{Rettslig bakgrunn}

Hovedformålslæren har utviklet sitt rettslige grunnlag fra en rekke høyesterettsdommer. I dommen inntatt i Rt. 2005 s. 1434 (Total) fremgår det at det etter "den alminnelig aksepterte hovedformålsbetraktning" er avgjørende "hvorvidt utgiftens tilknytning til inntektservervet objektivt sett fremstår som det vesentligste". ${ }^{62}$ Aarbakke skriver at det med hensyn til skatteyters formål er "avgjørende om de elementer som har karakter av erverv, er vesentlige eller ikke". ${ }^{63}$ Hovedformålslæren innebærer dermed at den vesenligste delen av formålet legges til grunn når formålet fremstår som blandet.

I Anth. B. Nilsen-dommen, var situasjonen at formålet bak en annonsekampanje både var å reklamere for skatteyters tjenester, men også å uttrykke uenighet med eksport- og næringspolitikken som ble ført i Norge på den tiden. Kun i en tredjedel av annonsene hadde Anth.

\footnotetext{
${ }^{60}$ Zimmer, 2009, s. 197, (3).

${ }^{61}$ Se Zimmer. 2009, s. 197.

${ }^{62}$ Rt. 2005 s. 1434 , avs. 44.

${ }^{63}$ Aarbakke, 1987, s. 263
} 
B. Nilsen uttrykkelig reklamert for sine tjenester, og ligningsmyndighetene hadde kun gitt fradrag for denne tredjedelen. Høyesterett kom imidlertid til at det også måtte gis fradrag for de andre annonsene fordi alle annonsene måtte sees i sammenheng. Dette begrunnet Høyesterett med at de alle samlet var "egnet til å bringe tanken hen på en viktig del av firmaets virksomhet" ${ }^{64}$ Høyesterett la altså vekt på at det ikke var avgjørende at formålet var blandet, så lenge det hovedsaklige formålet var å reklamere for selskapets tjenester. Med dette som hovedformål, var tilknytningen til selskapets inntektservervelse tilstrekkelig.

Denne linjen ble fulgt opp i Kosmos-dommen. Høyesterett kom til at det forelå to formål bak bygningsprosjektet: For det første at Kosmos hadde pådratt seg kostnaden for å få tilfredsstilt sitt behov for hotell- og kontorfasiliteter. For det andre ble formålet vurdert som et $\varnothing$ nske om å gi et positivt bidrag til byen og distriktet. Høyesterett vurderte saken slik at Kosmos bidro til bygget først og fremst for å dekke sine egne behov, og at dette formålet måtte bedømmes som det avgjørende.

\subsubsection{Hovedformålsæren i relasjon til sponsoravtaler}

Da fradragsretten skulle behandles i Skagen-saken, var en av Skagens anførsler at selv dersom det skulle foreligge et gaveelement i deler av kostnadene, måtte formålet sees under ett, der det kommersielle formålet var det avgjørende. Det ble i denne sammenheng vist til hovedformålslæren som grunnlag for anførselen. I Høyesteretts behandling av spørsmålet, ble denne anførselen avvist med begrunnelsen "ettersom det $i$ avtaleverket er foretatt en oppdeling av ytelsene som er godtatt av ligningsmyndighetene, er den skatterettslige hovedformålslare ikke relevant for løsningen" ${ }^{65}$ Dette utdraget forteller særlig to ting om formålets rolle i vurderingen av fradragsretten. For det første bekrefter det betydningen av skatteyters formuleringer og begrepsbruk i formelle avtaler, som beskrevet i avsnitt 3.3.2. For det andre forteller det at hovedformålslæren ikke kommer til anvendelse når skatteyter selv har foretatt en oppdeling av kostnaden etter formål og karakter.

${ }^{64}$ Se Rt. 1956 s. 1188 (s. 1190).

${ }^{65}$ Rt. 2012 s. 744, avs. 63. 


\subsubsection{Forholdsmessig fordeling}

Alternativet til å anvende hovedformålslæren der det påvises flere formål, er altså å foreta en forholdsmessig fordeling på grunnlag av hva som anses fradragsberettigete, og ikkefradragsberettigete kostnader. Denne fordelingen går nærmere bestemt ut på å vurdere verdien av kostnaden slik den fordeler seg til de ulike formålene, og dermed beregne det fradragsberettigete beløpet ut ifra dette.

\subsubsection{Rettslig bakgrunn}

Fremgangsmåten med å foreta en forholdsmessig fordeling, har bakgrunn i administrativ praksis, der ligningsmyndighetene har gitt fradrag for den delen av en kostnad som har relatert seg til inntektsskapende aktivitet. ${ }^{66}$ I Skagen-saken tillot Skatt vest fradrag kun for den delen av kostnadene som i avtalen ble kalt "Sponsoravgift". Høyesteretts stadfesting av denne løsningen kunne tyde på at man går bort fra hovedformålslæren og heller foretar en forholdsmessig oppdeling av kostnaden. I denne sammenheng er det imidlertid viktig å understreke at Skagens egen oppdeling i prosjektstøtte og sponsoravgift ble lagt til grunn. Det måtte dermed ikke foretas en skjønnsmessig vurdering av hvor mye av kostnaden som relaterte seg til markedsføring. Oppdelingen var også foretatt helt i tråd med en standard, vist i Skattedirektoratets veiledning "Merverdiavgift - for veldedige og allmennyttige organisasjoner og institusjoner". ${ }^{67}$ Denne standarden tar sikte på situasjoner der formålet nettopp er delt. Dette styrket formodningen om at formålet var delt i henholdsvis kommersielt og altruistisk motiverte ytelser. Denne eksplisitte oppdelingen skiller Skagen fra både Anth. B. Nilsen og Kosmos-saken. Dersom sponsoravtalene i Skagen ikke hadde inneholdt en slik begrepsmessig inndeling, er det derfor grunn til å stille spørsmålet om skattemyndighetene og Høyesterett hadde foretatt den samme fordelingen, eller i stedet fulgt hovedformålslæren som i de to andre dommene om fradragsrett.

\footnotetext{
66 Zimmer 2009 s. 197.

${ }^{67}$ Se http://www.skatteetaten.no/Upload/PDFer/Merverdiavgift/Brosjyreveldedige_2008.pdf (26.03.08), [Sitert 02.10.12].
} 
Dette er selvsagt et hypotetisk spørsmål, som ikke kan besvares med sikkerhet. Samtidig er det et viktig spørsmål, ettersom det sier noe om Skagen-dommens rekkevidde og dermed generelt om adgangen til å kreve fradrag for utgifter til sponsing. I jakten på et svar kan det være nyttig å komme nærmere inn på hvordan skattemyndighetene går frem i den skjønnsmessige fordelingen mellom fradragsberettigede og ikke-fradragsberettigede kostnader basert på de ulike formålene.

\subsubsection{Fordeling basert på reklameverdi}

Ligningspraksis vedrørende fradragsretten for markedsføringsutgifter tilsier at det ved tilfeller som det ovennevnte blir foretatt en skjønnsmessig fordeling basert på reklameverdien av motytelsene sponsor mottar ved å gi sitt bidrag. ${ }^{68}$ Sponsor får dermed kun fradrag for et beløp tilsvarende reklameverdien av mottakers motytelse. Denne fremgangsmåten er videre lagt til grunn i Lignings-ABC, hvor det fremgår at det fradragsberettigete beløpet er begrenset til reklameverdien av motytelsen. ${ }^{69}$ Videre kan det sies at denne fremgangsmåten også har støtte i rettspraksis. I Skagen-dommen ble det også gitt fradrag basert på hva ligningsmyndighetene oppfattet som reklameverdien av motytelsene Skagen oppnådde gjennom samarbeidsavtalene. Skatt vest hadde nemlig foretatt en beregning av reklameverdien Skagen oppnådde fra motytelsene etter avtalen, og fant at dette stemte med beløpet man allerede hadde gitt fradrag for. De eksplisitt nevnte motytelsene i Skagen gikk ut på at de ideelle organisasjonene pliktet å markedsføre Skagen gjennom sine medlemsblader, på nettsidene og Øvrige kommunikasjonskanaler. I tillegg skulle Skagen ha rett til å bruke de ideelle organisasjonenes logo i markedsføringen av seg selv. Hensikten med dette var å vise overfor kunder og publikum ellers at selskapet tok samfunnsansvar. I tillegg fikk Skagen retten til å bli betegnet som hovedsamarbeidspartner, samt at kunder og ansatte skulle få lov til å bli med på arrangementer i regi av de ideelle organisasjonene. Disse motytelsene

\footnotetext{
${ }^{68}$ Se Klagenemnda for oljeskatt, kjennelse av 25.2.2002: "Fradrag for bidrag til Stavanger Domkirke", og kjennelse av 25.2.2002: "Fradrag for utgifter til reklame /sponsorvirksomhet /gaver". ${ }^{69}$ Lignings-ABC 2012 s. 1075.
} 
ble verdsatt tilsvarende beløpet Skagen hadde betegnet som "markeds- og eksponeringsutgifter". ${ }^{70}$ Dette støtter opp under det generelle utgangspunktet om at fradragsretten for sponsorutgifter er begrenset til den reklamemessige verdien av de avtalte motytelsene. Der man er enige om at formålet er kommersielt, blir det neste spørsmålet hvor stort fradraget blir, ettersom verdien av reklame ikke er en opplagt størrelse.

\subsubsection{Reell reklameverdi}

Beregningen av reklameverdien av en motytelse har aldri blitt behandlet konkret av Høyesterett. Dette kan ha sammenheng med at domstolene generelt viser tilbakeholdenhet med å overprøve ligningsmyndighetenes skjønnsutøvelse der denne fremstår som godt begrunnet og veloverveid. ${ }^{71}$ I Skagen-dommen ga Høyesterett tilslutning til ligningsmyndighetenes skjønnsutøvelse ved vurderingen av reklameverdien. ${ }^{72}$ I denne saken ble reklameverdien av motytelsene vurdert til et beløp tilsvarende hva annonser i aviser og på internett hadde kostet. Det er grunn til å tro at denne fremgangsmåten er fast praksis for saker der formålet er delt. I ligningspraksis betegnes den fradragsberettigete delen av motytelsen som motytelsens "reelle reklameverdi". Denne størrelsen tilsvarer hva skatteyter måtte ha betalt for rubrikkannonser $\mathrm{i}$ aviser og lignende, $\mathrm{i}$ et omfang og opplag, tilsvarende annonseringen som følger av sponsoravtalen. Det er altså ikke nødvendigvis den verdien markedsføringen har for skatteyter som er relevant.

Videre innebærer dette at det ikke skilles mellom ulike markedsføringsstrategier i vurderingen av den reklamemessige verdien. For eksempel vil man gjennom et sponsorsamarbeid kunne ha relativt store utgifter målt opp mot markedsprisen for rubrikkannonser i aviser. Samtidig er man villig til å betale det overskytende i et sponsorsamarbeid fordi man mener å få noe mer tilbake enn det en gjennomsnittlig rubrikkannonse vil gi, for eksempel gjennom $\emptyset \mathrm{kt}$ assosiasjonsverdi og goodwill fra kundemassen. Ved en verdivurdering basert

\footnotetext{
${ }^{70}$ Se Rt. 2012 s. 744 , avs. 50.

${ }^{71}$ Se Rt. 2009 s. 105 , avs. 112 og Rt. 2010 s. 527, avs. 47.

${ }^{72}$ Se Rt. 2012 s. 744 , avs. 62.
} 
på hva rubrikkannonser av et tilsvarende omfang som annonsene gjennom sponsorsamarbeidet innebærer, vil ikke assosiasjonsverdi og goodwill bli fanget opp i beregningen av fradraget. Dette synspunktet ble lagt til grunn i tingretten, og av mindretallet i lagmannsretten, i Skagen-saken. ${ }^{73}$ Ettersom en beregning basert på "reell reklameverdi" ble godkjent av flertallet i lagmannsretten og stadfestet av Høyesterett, er det imidlertid ikke tvil om at denne beregningsmetoden er gjeldende rett. Beregningsmetoden kan forsvares med at det tilsynelatende er den eneste praktisk mulige måten å foreta en verdivurdering på. Som nevnt i pkt. 1.3, hersker det tvil om virkningene av sponsing. Dermed er det også vanskelig å fastslå verdien av den delen av sponsorutgiftene som relaterer seg til mer uhåndgripelige virkninger, slik som assosiasjonsverdi og goodwill.

Det kan spørres om fradraget begrenses til et beløp tilsvarende "reell reklameverdi" også der skatteyter ikke har foretatt en begrepsmessig oppdeling av ytelsene, slik man hadde gjort i Skagen. ${ }^{74}$ Dette har betydning for hvor avgjørende skatteyters formelle avtaler og begrepsbruk er for størrelsen på fradraget. Som nevnt har ikke spørsmålet vært oppe i rettspraksis, annet enn i Skagen-saken. Ligningspraksis tilsier imidlertid at det foretas en beregning av den reelle reklameverdien av motytelsene i sponsorsamarbeidet, også der det ikke er foretatt en begrepsmessig oppdeling av ytelsene. ${ }^{75}$ Dette skjer gjerne der det er tvil om formålet bak kostnaden. Med henblikk på det som er skrevet om domstolenes tilbakeholdenhet ved prøvingen av ligningsmyndighetens skjønnsutøvelse, er det grunn til å tro at denne løsningen også godtas av domstolene. ${ }^{76}$ Dette taler dermed for at begrepsbruken i avtaler ikke er avgjørende for om fradraget begrenses til "reell reklameverdi" eller ikke. Særlig må dette være tilfellet der formålet fremstår som uklart.

\footnotetext{
73 Se Utv. 2011 s. 1380, Gulating Lagmannsrett og Utv. 2010 s. 1434, Stavanger Tingrett.

${ }^{74}$ Se avs. 3.3.2.

${ }^{75}$ Se bl.a. Klagenemnda for oljeskatt, kjennelse av 19.11.2007: "Fradrag for bidrag til et kunnskapssenter", Klagenemnda for oljeskatt, kjennelse av 25.2.2002: "Fradrag for bidrag til Stavanger Domkirke" og kjennelse av 25.2.2002: "Fradrag for utgifter til reklame /sponsorvirksomhet /gaver".

${ }^{76}$ Se avs. 3.5.3.3.
} 


\subsection{Oppsummering}

Ovenfor er det redegjort for hvilke kriterier som er relevante ved fastleggelsen av skatteyters formål i vurderingen av om tilknytningsvilkåret er oppfylt. Det er også forsøkt å gjøre rede for bakgrunnen for fremgangsmåten som er valgt i rettspraksis. Hvor grundig og konkret fastleggelsen av skatteyters formål skjer, kan se ut til å komme an på hvor uklart eller tvetydig formålet fremstår i den enkelte sak. Hvor tydelig det kommersielle aspektet ved formålet må fremstå utad for å etablere tilstrekkelig tilknytning til skatteyters inntekt, er også vanskelig å fastslå generelt. En tendens ser ut til å være at dersom formålet fremstår som tvetydig, stilles høyere krav til et ytre skinn av kommersielle hensikter. I Skagendommen forelå det konkrete, positivt angitte holdepunkter i avtaler mv., som utad tilsa at de omstridte ytelsene ble overført uten krav om motytelser. Dette påvirker dommens rekkevidde ved at man ikke kan overføre den samme formålsvurderingen til saker der slike holdepunkter ikke foreligger. En kan spørre hvordan formålet i Skagen-saken hadde blitt konstatert dersom man ikke hadde foretatt den begrepsmessige oppdelingen av ytelsene. Dette har betydning for hvordan skatteyter og sponsor burde innrette seg dersom hensiktene er kommersielle og fradrag ønskes. Høyesteretts fokus på objektive kjennetegn i tilknytningsvurderingen i Skagen-dommen, medfører at skatteyter i alle tilfeller må ha et bevisst forhold til hvordan kostnadene fremstår utad. For at formålet skal kunne bidra til å oppfylle tilknytningsvilkåret, må det dermed etter gjeldende rett også utad fremstå som kommersielt. I tilfeller der sponsorsamarbeidet ikke fremstår som utpreget kommersielt, taler det foreliggende rettskildebildet for at den reelle reklameverdien danner rammen for fradragsberegningen. 


\section{Kravet til kostnadens egnethet}

\subsection{Innledning og rettslig utgangspunkt}

Avhandlingens hoveddel har til nå tatt sikte på å behandle formålets betydning som tilknytningsvilkår samt situasjonen som oppstår der det foreligger flere formål bak skatteyters kostnad. Det neste spørsmålet er om et kommersielt formål er tilstrekkelig for å oppfylle tilknytningsvilkåret, eller om det samtidig stilles ytterligere krav til kostnaden.

I vurderingen av om det foreligger tilstrekkelig tilknytning mellom kostnad og skattepliktig inntekt, har det i rettspraksis og teori også vært diskutert om det stilles krav til kostnadens evne til å $\emptyset$ ke skatteyters inntekt. Temaet for diskusjon har vært om kostnaden må være egnet til å generere inntekt for skatteyter. ${ }^{77}$ Aarbakke betrakter tilsynelatende kostnadens objektive egnethet som det avgjørende kriteriet i tilknytningsvurderingen. ${ }^{78}$ At objektiv egnethet er en forutsetning for fradrag, har videre blitt anført av skattemyndighetene i en rekke saker, hvorav enkelte har nådd Høyesterett. ${ }^{79}$ Et relevant spørsmål er derfor i hvilken grad egnethet er et kriterium for fradrag for sponsorutgifter. Som nevnt innledningsvis er sponsingens egnethet som markedsføringsmiddel et omdiskutert tema, ikke bare i skatterettslige miljøer, men også i fagmiljøer for markedsføring.

Det kan først slås fast at det ut ifra dagens rettstilstand ikke stilles noe strengt krav til kostnadens egnethet når fradragsretten skal vurderes, så lenge formålet er erverv mv. av skattepliktig inntekt. En prinsipiell uttalelse om dette fremgår av Høyesteretts dom inntatt i Rt. 1981 s. 256 (Bjerke-Pedersen). Saken dreide seg om en forsikringsagent som investerte 100 000 kroner i en joint venture-avtale, med henblikk på å overta forsikringsavtalene samarbeidet brakte. Prosjektet ble stilt i bero og investeringen i avtalen gikk tapt. Forsikringsagenten krevde fradrag for dette tapet, som en kostnad til inntekts ervervelse. Dette ble ikke godtatt av skattemyndighetene. Skattemyndighetene anførte at investeringen ikke var egnet

\footnotetext{
${ }^{77}$ Zimmer, 2009 s. 193.

${ }^{78}$ Aarbakke, 1987, s. 265, avs. 29.6.2.

${ }^{79}$ Se bla. Rt. 1981 s. 256 , Rt. 2007 s. 1822 og Rt. 2009 s. 1467.
} 
til å skape inntekt, og at den derfor ikke var fradragsberettiget. Høyesterett var uenig i dette, og uttalte:

"Jeg vil ikke utelukke at en utgift med sikte på å oppnå fremtidige inntekter kan vare så uegnet for formålet at den allerede av denne grunn ikke kan aksepteres som utgift $i$ inntektens ervervelse. Men når det - som i denne sak - er uomtvistet at skatteyters formål med utgiften har vart å fremme erverv av inntekt, kan det etter min oppfatning bare i rene unntakstilfelle bli tale om å nekte fradrag fordi utgiften objektivt sett ikke var formålstjenelig.". ${ }^{80}$

Uttalelsen forteller særlig to ting om eventuelle krav til kostnadens egnethet som generelt fradragskriterium. Det ene er at det ikke kan utelukkes tilfeller der kostnaden ansees så uegnet at det allerede av denne grunn ikke gis fradrag. Det andre er at så lenge skatteyters formål har vært å fremme inntektservervelsen, skal det svært mye til før fradrag nektes fordi kostnaden ikke er egnet. Dette taler i retning av at det heller ikke kan oppstilles et strengt krav til egnethet for kostnader til sponsing, så lenge formålet er kommersielt.

\subsection{Samvariasjonen mellom formål og egnethet}

De sistnevnte slutningene bringer fokuset over på sammenhengen mellom skatteyters formål og kostnadens objektive egnethet til å påvirke skatteyters inntekt. Med utgangspunkt $\mathrm{i}$ slutningen om at det ikke stilles strenge krav til objektiv egnethet så lenge formålet tilsier at tilknytningsvilkåret er oppfylt, kan det spørres om og hvordan kravet til egnethet endres der formålet fremstår som uklart. Ut ifra det som har blitt nevnt hittil, ser det ut til at det er en samvariasjon mellom formål og egnethet, ved at det stilles strengere krav til egnethet ved uklart formål, enn der formålet tydelig har sammenheng med skatteyters inntektservervelse.

\footnotetext{
${ }^{80}$ Se Rt. 1981 s. 256 , avs. 19.
} 
Det finnes ingen klare regler om hvordan kostnadens egnethet og formål vektes opp mot hverandre. Noen utgangspunkter kan likevel søkes i rettspraksis. I Bjerke-Pedersen ble det betraktet som opplagt at formålet bak joint venture-avtalen var å fremme inntektservervelse gjennom overtakelse av forsikringsavtalene. At muligheten for $\emptyset \mathrm{kt}$ inntekt på ingen måte var sikker, ble derfor ikke tillagt vekt. Det samme standpunktet ble tatt i Samdal: Det ble betraktet som opplagt at formålet bak eiendomsinvesteringen var økt kapitalavkastning. Høyesterett gikk ikke inn på en vurdering av investeringenes egnethet, men uttalte snarere at "Domstolane skal ikkje sensurere forretningsskjønnet til den som gjennomfører ei investering eller tek på seg ein kostnad". ${ }^{81}$ Uttalelsen, sett i sin kontekst, kan tolkes slik at så lenge skatteyter pådrar seg kostnaden med hensikt om å skape inntekt, skal verken skattemyndigheter eller domstoler gå inn og prøve hvor formålstjenelig kostnaden er. I relasjon til sponsing, taler dette for at det er skatteyters vurdering som må være avgjørende for hva slags markedsføring som fremmer inntektservervet.

Et annet relevant moment er at kostnadens egnethet kan brukes i prosessen med å fastslå skatteyters formål. Kostnadens natur kan gi en mer eller mindre sterk formodning om hva hensikten bak kostnaden er. Kostnadens egnethet er dermed en ytre indikasjon på hvilke hensikter som ligger bak formålet. Hvor nyttig kostnadens egnethet er for å konstatere formålet kommer an på hvor mye kostnadens natur skiller seg ut fra skatteyters alminnelige virksomhet. I Kosmos-dommen ble kostnadens egnethet brukt som moment da skatteyters formål skulle vurderes. Høyesterett uttalte i denne sammenheng "Jeg finner også at en medvirkning fra selskapets side til realiseringen av byggeplanene objektivt sett fremtrer som egnet til å fremme selskapets formål". ${ }^{82}$ Formodningen om at kostnaden ble pådratt for å fremme selskapets virksomhet ble dermed styrket av at kostnaden fremsto som egnet.

\footnotetext{
${ }^{81}$ Se Rt. 2009 s. 1467 , avs. 37.

${ }^{82}$ Rt. 1967 s. 954, avs. 11.
} 


\subsection{Kravet til egnethet ved sponsorsamarbeid}

De foreløpige slutningene om egnethetskriteriet er nyttige å trekke med seg i vurderingen av hvilke krav som stilles til et sponsorsamarbeids egnethet i fradragsvurderingen. Spørsmålet er hva som skal til for at et sponsorsamarbeid skal anses som så uegnet at det ikke gis fradrag allerede av denne grunn.

Det kan tenkes praktiske tilfeller der et sponsorsamarbeid anses uegnet til å fremme skatteyters inntekt. Gjennom et sponsorsamarbeid ønsker sponsor at publikums positive assosiasjoner til en idrettsutøver, kulturinstitusjon eller ideell organisasjon skal smitte over på sponsors virksomhet eller produkt. Dette skal igjen føre til at publikum foretrekker sponsorens produkter eller tjenester fremfor konkurrentenes. ${ }^{83}$ Det er imidlertid knyttet usikkerhet til om dette faktisk skjer. Resultatet er avhengig av hvor naturlig produkt og sponsor passer sammen, samt abstraksjonsnivået som velges i sponsingskampanjen. ${ }^{84}$ Nettopp denne usikkerheten rundt effekten av markedsføringen, kan medføre at kostnadene til samarbeidet ikke betraktes som egnet til å etablere tilstrekkelig tilknytning mellom skatteyter og kostnad.

Et lignende standpunkt ble tatt i dommen inntatt i Rt. 1949 s. 912. Saken dreide seg om hvorvidt tilskudd til en forening som arbeidet med promotering av Folketeateret skulle kunne kreves fradragsført. Høyesteretts flertall kom her til at det gjennom dette tilskuddet ikke forelå "en så nar og påtagelig forbindelse mellom utgiften og den påregnede fremtidige inntekt" at det kunne kreves fradrag. ${ }^{85}$ Denne uttalelsen har senere blitt vektlagt i rettspraksis, der tilknytningsvilkåret har vært tema. ${ }^{86} \mathrm{Et}$ moment som kan trekkes ut av uttalelsen er at det finnes en grense for hvor fjerntliggende avkastningen på kostnaden kan være både i tid og sannsynlighet for at det skal kunne kreves fradrag for kostnaden. I relasjon til

\footnotetext{
${ }^{83}$ Siv Skard: "Sponsing - tid for å åpne den sorte boks". Kampanje nr. 1. 2009.

${ }^{84}$ M. J. Polonsky, R. Speed: "Linked Sponsorship and cause related marketing, Complementarities and Conflicts". European Journal of Marketing. 2001. s. 1361.

${ }^{85}$ Rt. 1949 s. 912.

${ }^{86}$ Rt. 2008 s. 794 og Rt. 2012 s. 744.
} 
sponsorsamarbeid kan det anføres at det kreves en viss påregnelighet og nærhet i tid med hensyn til avkastning, for at utgiftene kan fradragsføres. De nyere refererte dommene (Kosmos og Bjerke-Pedersen) tyder imidlertid på at det har skjedd en liberalisering rundt kravet til egnethet, der skatteyters egne vurderinger av egnetheten er avgjørende. Uavhengig av dette, finnes det som nevnt fortsatt en grense for hvor uegnet en kostnad kan være for at det skal kunne gis fradrag.

Med henvisning til det som er nevnt om sponsingens rolle som markedsføringsmiddel innledningsvis, under 1.1, er det åpenbart at mange norske bedrifter anser sponsing som et markedsføringsmiddel som bidrar til $\emptyset \mathrm{kt}$ omsetning. Dersom man skal legge skatteyters eget forretningsskjønn til grunn, må sponsorutgifter derfor ofte anses egnede til å fremme skatteyters inntekt. Man kommer imidlertid ikke langt med å foreta en generell vurdering av sponsoravtaler som verktøy for $\varnothing \mathrm{kt}$ omsetning. Sponsing omfatter som nevnt mange ulike markedsføringstiltak, der bl.a. sponsorobjekt, sponsorobjektets forpliktelser og påviselig effekt av sponsingen varierer. Det er derfor grunn til å gå nærmere inn på disse ulike egenskapene ved sponsing, og knytte de opp mot egnethetsvurderingen.

\subsection{Betydningen av sponsorobjektet som velges}

Spørsmålet som reises i dette avsnittet er om sponsorobjektet som velges, har betydning for om kravet til objektiv egnethet anses oppfylt.

Oppfatningen av hvilke kostnader og investeringer som må anses objektivt egnet til å fremme en virksomhets inntekter vil ofte påvirkes av hva man intuitivt betrakter som egnet. En velkjent markedsføringsmetode vil derfor presumptivt enklere oppfattes som egnet, enn markedsføring man ikke har sett tidligere. Man vil derfor uten problemer kunne ha en oppfatning om at sponsingen av et fotballag vil være egnet til å fremme virksomhetsinntektene, fordi det er kjent at man da har mulighet til å få virksomhetens logo på fotballdraktene, som igjen vises på TV. Samtidig vil man ikke like lett kunne mene at et økonomisk bidrag til en ideell organisasjon er egnet på samme måte. Det foreligger faktiske forskjeller mellom disse metodene, som påvirker vår oppfatning av hva som er et egnet, og hva som ikke er et 
egnet sponsorobjekt. Hvilke motytelser som er avtalt med de ulike sponsorobjektene er for eksempel selvsagt av betydning. Dette behandles nærmere under kapittel 4.6. Men det kan også tenkes at våre tradisjonelle oppfatninger av reklame er styrende for hvor egnet vi anser ulike sponsorsamarbeid for å være. Når skattemyndigheter og domstoler skal foreta vurderingen av sponsingens egnethet, er det derfor interessant om valget av sponsorobjekt $\mathrm{i}$ seg selv, er av betydning.

\subsection{Sammenhengen mellom sponsor og sponsorobjekt}

I vurderingen av kostnadens egnethet, kan det spørres om man i større grad aksepterer tilknytningsvilkåret som oppfylt i tilfeller der sponsorobjektet har en naturlig sammenheng med sponsors virksomhet. I slike tilfeller kan det tenkes at dette er et moment som både tilsier at formålet er kommersielt og at sponsoravtalen er egnet til å fremme sponsors inntektserverv. I markedsføringsbransjen betegnes sammenhengen mellom sponsor og sponsorobjekt som "fit". ${ }^{87}$ Dette engelske begrepet omhandler hvor naturlig sammenheng det er mellom sponsor og sponsorobjekt. Et eksempel er der Swix sponser langrennslandslaget med skismøring og skidresser mot at skiløperne stiller opp i TV-intervjuer med skidressene og dermed eksponerer sponsors logo. Det er en åpenbar sammenheng mellom sponsors virksomhet og sponsorobjekt, noe som antas å skape $\emptyset \mathrm{kt}$ salg av sponsors produkter. I slike tilfeller er det ikke vanskelig å konkludere med egnethet. Dette har sammenheng med at avstanden til tradisjonell reklame er liten. Men dette kan samtidig skyldes at linken mellom sponsor og sponsorobjekt er så åpenbar.

Også ved mindre åpenbare sammenhenger mellom sponsor og -objekt kan det tenkes å være snakk om en tiltenkt "fit". Merzedes-Benz Norge inngikk som nevnt en sponsoravtale med Den norske opera i 2007. Det ble i denne sammenheng avholdt en pressekonferanse, hvor administrerende direktør i Mercedes-Benz Norge, Arne Berg, uttalte seg om bakgrunnen for samarbeidet:

\footnotetext{
${ }^{87}$ Se Skard, Siv. 2011. "Hvordan virker egentlig sponsing?". Magma 4 (11).
} 
"Verdisettet som Den Norske Opera har er svart sammenfallende med våre i Mercedes-Benz. «Kvalitet» er ett eksempel. Jeg kan ikke komme på noen annen institusjon eller virksomhet som står mer for kvalitet enn Den Norske Opera. «Tradisjoner» er også dekkende for Den Norske Opera, og det samme må man vel kunne si om oss som verdens eldste bilprodusent. Men også selve bygget understreker det moderne og fremtidsrettede. Foryngelse av merkevaren er også felles for både Den Norske Opera og Mercedes-Benz". ${ }^{88}$

Selv om samarbeidspartnerne ikke var i samme bransje, anså Mercedes-Benz Den norske opera som en egnet arena for å markedsføre seg selv gjennom å skape en link mellom seg selv og sponsorobjektet. Gjennom denne formen for markedsføring forsøker sponsor å få publikums positive assosiasjoner til å smitte over på seg selv.

Man finner også tilfeller av sponsing der det tilsynelatende er motstrid mellom sponsorobjekt og sponsor. Dette kan imidlertid være et bevisst valg fra sponsors side, og betegnes gjerne som en "non-fit" mellom partene i sponsorsamarbeidet. Et eksempel er sponsorsamarbeidet mellom langrennsutøver Petter Northug og energidrikken Red Bull. ${ }^{89}$ Dette er to objekter som ikke har et naturlig sammenfallende image fra tidligere, ved at langrennssporten gjerne forbindes med noe urnorsk og sunt, imens Red Bull gjerne forbindes med ekstremsport, og var forbudt i flere land på grunn av høyt koffeininnhold. ${ }^{90}$ Hensikten bak sponsorsamarbeidet kan være å overbevise om at avstanden mellom energidrikken og langrennssporten ikke er så stor likevel, og den opprinnelige oppfatningen av "non-fit" skaper oppmerksomheten som trengs for å kommunisere dette.

\footnotetext{
${ }^{88}$ Midsjø, Line. Kampanje. http://www.kampanje.com/markedsforing/article5250637.ece (publisert 28.03.07) [sitert 10.10.12].

${ }^{89}$ Se Folkestad, Sigrid: "Mye å tjene på smartere sponsing". NHH Bulletin. http://www.forskning.no/artikler/2010/juni/252650 (Oppdatert 17.07.10) [sitert 18.10.12].

${ }^{90}$ Gimnes, Lasse, Sponsor- og eventforeningen: "Satte Red Bull på dagsordenen". http://sponsorogeventforeningen.no/sider/tekst.asp?side=694 (Oppdatert 15.10.12.). [Sitert 17.10.12.].
} 
Denne strategien kan overføres til Skagen-saken, der man heller ikke har noen øyeblikkelig sammenheng mellom SOS-barnebyer og CARF på den ene siden, og et finansforetak (Skagen fondene) på den annen. Ideelle organisasjoner forbindes ofte med myke, medmenneskelige verdier imens finansforetak heller forbindes med et fokus på profittmaksimering. Skagens sponsing av de to organisasjonene kan sees som et forsøk på å skille seg fra bransjens image, som kommersielle profittjegere uten bevisste holdninger til sosialt ansvar. Uavhengig av om man er enig i at dette lyktes i det konkrete tilfellet eller ikke, er det lett å se at denne formen for markedsføring er mindre tradisjonell enn eksempelet med sponsing av et fotball- eller langrennslag. Man er da tilbake på utgangspunktet om at den intuitive oppfatningen av sponsingens egnethet, avhenger av i hvilken grad man har sett dette bli gjort tidligere.

Det foreligger ikke rettspraksis som direkte tilsier at sponsorobjektet har betydning for fradragsretten. Ligningspraksis viser imidlertid at skattemyndighetene også godtar fradrag i tilfeller der det ikke er noen opplagt forbindelse mellom sponsor og sponsorobjekt. ${ }^{91}$ Det kan likevel tenkes at sammenhengen mellom sponsor og sponsorobjekt spiller inn i den konkrete vurderingen av kostnadens objektive egnethet. ${ }^{92}$ Den til dels lite håndfaste naturen av et sponsorsamarbeid tilsier at tilknytningen mellom kostnaden og skatteyters inntekt primært søkes i mer objektivt konstaterbare momenter. Motytelsenes betydning i tilknytningsvurderingen behandles i det følgende.

\subsection{Krav om håndgripelig motytelse?}

\subsubsection{Innledning og rettslig utgangspunkt}

Utgangspunktene rundt hvilke krav som stilles til kostnadens egnethet er nå behandlet. I et sponsorsamarbeid utgjør motytelsene som oppnås et svært viktig moment i egnethetsvurde-

\footnotetext{
${ }^{91}$ Se f.eks. Fløystad: Ligningsbehandlingen 1999, pkt. 3.4. der et utvinningsselskap fikk fradrag for støtte til en musikkfestival. Det ble her lagt vekt på selskapets avtalte profileringsrettigheter under festivalen.

${ }^{92}$ Se avs. 3.3.1.
} 
ringen. Hvilke motytelser som er avtalt, er nemlig avgjørende i vurderingen av om man står overfor en gaveoverføring. ${ }^{93}$ Det skatterettslige utgangspunktet om at det ikke gis fradrag for gaver gjør dermed motytelsene helt sentrale i tilknytningsvurderingen. I det følgende behandles nærmere hva som kreves av motytelsen i et sponsorarbeid for at tilknytningsvilkåret skal ansees oppfylt.

Ut ifra det som er skrevet om de milde kravene til kostnadens egnethet, stilles det ikke strenge krav til motytelsenes kvalitative egenskaper. ${ }^{94}$ Dette har sammenheng med det som er skrevet om ligningsmyndigheter og domstolers anerkjennelse av skatteyters forretningsskjønn. ${ }^{95}$ Samtidig må det foreligge en viss minstestandard. I Skagen anførte skatteyter at mottakerorganisasjonene ville bidra til å skape en assosiasjonsverdi for skatteyter. Dette skulle skje ved at Skagens ansatte og kunder skulle gis mulighet til å bes $ø$ ke de veldedige organisasjonenes prosjekter for å skape trivsel blant ansatte og styrke Skagens image som en samfunnsansvarlig bedrift. I tillegg skulle mottakerorganisasjonene benytte sponsormidlene til konkrete veldedighetsprosjekter i utlandet, som skulle oppkalles etter skatteyter. I vurderingen av om dette var motytelser som skapte tilstrekkelig tilknytning, uttalte Høyesterett:
"Fravaret av motytelser som lar seg verdsette, fører til at det er vanskelig å etable- re den type tilknytning mellom kostnaden og sikring mv. av skattepliktig inntekt som \$ 6-1 krever. Det er jo ikke avtalt at mottakeren skal prestere noe som kan gi give- ren grunnlag for inntekt. Tilknytningen mellom kostnaden og en potensiell inntekt blir med andre ord svert løs, om noen tilknytning overhodet." ${ }^{196}$

Uttalelsen tilsier at motytelsene må ha en viss substans. De ideelle organisasjonenes forpliktelser til å markedsføre Skagen bla. gjennom logoeksponering i sine egne publikasjo-

\footnotetext{
${ }^{93}$ Se avs. 3.2.1. og Lignings-ABC 2012 s. 680.

${ }^{94}$ Avs. 4.1.

${ }^{95}$ Se avs. 4.2.

${ }^{96}$ Se Rt. 2012 s. 744 , avs. 56.
} 
ner, ble som kjent ansett som tilstrekkelig håndgripelige motytelser. De mer avledete effektene av samarbeidet ble imidlertid ikke ansett som motytelser egnet til å etablere tilstrekkelig tilknytning.

\subsection{2 Økonomisk verdi}

I Skagen vektlegger Høyesterett at det ikke foreligger motytelser "som lar seg verdsette", ref. ovenfor. Dette tyder på at motytelsen må være av konkret økonomisk verdi for å kunne bidra til å oppfylle tilknytningsvilkåret. Ut ifra det som er skrevet om beregningen av reell reklameverdi i avsnitt 3.5.3.3, kan dette medføre at assosiasjonsverdien ikke fanges opp i verdivurderingen og av den grunn ikke ansees som en håndgripelig motytelse. Denne betraktingen vil det bli redegjort for nærmere, under kapittel 5. En klar slutning er imidlertid at dersom man kan konstatere at et sponsorsamarbeid har reell reklameverdi, utgjør dette et selvstendig og objektivt konstaterbart moment i tilknytningsvurderingen. Påvisning av at motytelsene som oppnås har reell økonomisk verdi, bidrar derfor til at det gis fradrag.

\subsubsection{Betydningen av at motytelsen er tilgjengelig for alle}

Ikke hvilken som helst verdi kan påberopes som motytelse fra sponsor. Dersom motytelsen som påberopes er tilgjengelig uavhengig av en opprinnelig ytelse fra sponsor, taler dette for at det ikke foreligger tilstrekkelig tilknytning. Et eksempel på dette fra rettspraksis, er Folketeater-dommen, referert til i avsnitt 4.3. Folketeateret krevde fradrag for et bidrag det hadde betalt til en forening - "Folketeaterforeningen" - for at foreningen skulle promotere teateret blant publikum. Folketeateret hadde på denne tiden ikke startet opp enda. Det var således ingen kommersiell drift av teateret da saken kom opp. Flertallet i Høyesterett kom som nevnt til at det ikke forelå "en så naer og påtagelig forbindelse mellom utgiften og den påregnede, fremtidige inntekt at den nevnte fradragsregel kan komme til anvendelse". ${ }^{97}$ Som del av begrunnelsen for dette, ble det lagt vekt på at foreningens promotering av teater

${ }^{97}$ Rt. 1949 s. 912 
som kulturtilbud ikke bare gagnet Folketeateret spesielt, men også alle andre teatre i Oslo. Motytelsen det her dreide seg om, medførte dermed ikke en motytelse utelukkende ytt til Folketeateret. Dommen er avsagt for over 60 år siden, men har senere blitt sitert både $\mathrm{i}$ Korsvold- og Skagen-dommen i forbindelse med fastleggingen av tilknytningsvilkårets rettslige innhold. ${ }^{98}$ Til tross for den omfattende samfunnsutviklingen etter at dommen ble avsagt har den dermed blitt tillagt vekt i nyere tid.

Et moment av relevans for vurderingen av motytelsens håndgripelighet, er dermed om motytelsen ikke bare kommer sponsor til gode, men også alle andre. Som praktisk eksempel kan tenkes dersom de ideelle organisasjonene i Skagen-saken hadde tillatt alle å besøke prosjektene deres i utlandet, og ikke bare sponsorene. I slike tilfeller kan man slutte at det ikke engang dreier seg om en egentlig motytelse, ettersom "motytelsen" ikke er forutsatt av noen opprinnelig ytelse. En tilsvarende betraktning kan anføres dersom alle som bidrar med et ubetydelig beløp, oppnår den samme fordelen som den som betaler mye. Basert på det som er skrevet om beregningen av reell reklameverdi, vil det fradragsberettigete beløpet ved slike tilfeller uansett reduseres betraktelig. ${ }^{99}$

Tolkningsmomentet om at motytelsen ikke etablerer tilknytning dersom den kan oppnås av alle, kan ikke uten videre legges til grunn. Det kan tenkes tilfeller der motytelsen kommer alle til gode, uten at dette medfører at tilknytningen er for løs. Et eksempel kan utledes fra en bindende forhåndsuttalelse fra Skattedirektoratet, avgitt i $2010 .{ }^{100}$ Saken dreide seg om en produsent av anleggsmaskiner, som holdt til på en $\emptyset \mathrm{y}$ på vestlandet. Selskapet $\emptyset$ nsket å gi tilskudd til byggingen av en bro for å etablere uavbrutt veiforbindelse til fastlandet. Behovet for en bro var begrunnet i et ønske om å øke markedstilgangen for egne produkter, samt å øke tilgangen på arbeidskraft. Selskapet henvendte seg til Skattedirektoratet for å få svar på om det ville gis fradrag for tilskuddet etter sktl. § 6-1. Skattedirektoratet kom her til at det forelå tilstrekkelig tilknytning, fordi broen ville bidra til økt omsetning for bedriften.

\footnotetext{
${ }^{98}$ Se Rt. 2008 s. 794 , avs. 47 og Rt. 2012 s. 744, avs. 44.

${ }^{99}$ Se avs. 3.5.3.3.

${ }^{100}$ BFU 23/10, avgitt 09.09.2010.
} 
Selv om broen, "motytelsen" for tilskuddet, ville komme alle beboere på øya til gode, ville Skattedirektoratet tillate det fradragsført. I denne saken var det imidlertid uomtvistet at formålet var å øke omsetningen.

\subsubsection{Samvariasjonen mellom formål og motytelser}

På samme måte som med kriteriet om egnethet generelt, avhenger hvilke krav som stilles til motytelsen av hvor tydelig formålet fremstår utad. Der formålet er uklart, kreves en tydeligere og mer håndgripelig motytelse. Der formålet er klart kommersielt, kreves mindre. Til illustrasjon, tjener Bjerke-Pedersen-dommen som eksempel. I behandlingen av tilknytningsvilkåret, uttalte Høyesterett:

"Bjerke Pedersen oppnådde ingen annen motverdi for sin oppofrelse enn en usikker forhåpning om at avtalen kunne lede til aktiviteter som igjen kunne gi ham adgang til å tegne forsikringer med derav følgende provisjonsinntekter. Det ligger etter min oppfatning noer å trekke en parallell med utgifter til markedsføring", ${ }^{101}$

I denne saken ble Bjerke-Pedersen innrømmet fradragsrett for utgiftene til joint ventureavtalen selv om avtalen ikke innebar noen konkret motytelse relatert til hans virksomhet, men kun en vag forhåpning om flere forsikringsoppdrag. Uttalelsen eksemplifiserer samvariasjonen mellom formål og krav til konkrete motytelser. I denne saken var det uomtvistet at Bjerke-Pedersens formål var å øke skattepliktig inntekt. Når dette var på det rene ble det derfor ikke stilt noe krav om håndgripelige motytelser.

Når det dreier seg om sponsorsamarbeid der formålet kan fremstå som uklart eller delt, og dermed ikke alene medfører at tilknytningsvilkåret er oppfylt, kan det derfor bidra til oppklaring å foreta en kvalitativ vurdering av motytelsene som er avtalt. I Skagen-dommen ble de avtalte motytelsene et avgjørende moment i vurderingen av fradragsretten. Høyesterett

${ }^{101}$ Se Rt. 1981 s. 256, avs. 18. 
uttaler at de ytre objektive kjennetegnene tilsier at Skagen har hatt til formål å berike de ideelle organisasjonene "uten å kreve andre motytelser enn å markedsføre selskapet og det sosiale ansvar foretaket viser på denne måten". ${ }^{102}$ Det er uklart om Høyesterett med denne uttalelsen søker å belyse Skagens formål, kostnadens egnethet, motytelsens håndgripelighet, eller alt samlet. Uttalelsen bekrefter imidlertid at håndgripelige motytelser utgjør et relevant moment i vurderingen av tilknytningsvilkåret.

\subsection{Oppsummering}

Behandlingen ovenfor illustrerer at kravet til egnethet har flere sider som bør tas i betraktning ved vurderingen av fradragsretten for sponsorutgifter. Rettspraksis viser at det skal mye til for at kostnadens egnethet alene skal medføre at det ikke gis fradrag. I vurderingen av kriteriet bidrar avtalte motytelser og sponsorobjektet som velges til å styrke eller svekke tilknytningen mellom kostnad og skatteyters inntekt. Dersom det er avtalt håndgripelige motytelser, bidrar dette i stor grad til å oppfylle tilknytningskriteriet ved fradragsvurderingen.

Behandlingen av egnethetskriteriet viser også at kriteriets vekt er relativ og må vurderes i sammenheng med skatteyters formål bak kostnaden. Dersom skatteyters formål er utvilsomt kommersielt, stilles mildere krav til kostnadens egnethet enn dersom formålet er tvetydig. Samvariasjonen mellom formål og egnethet illustrerer tilknytningsvilkårets skjønnsmessige karakter, der momentene må vurderes i sammenheng med hverandre for å kunne vurdere fradragsadgangen.

${ }^{102}$ Se Rt. 2012 s. 744, avs. 53. 


\section{Assosiasjonsverdiens rolle i tilknytningsvurderingen}

\subsection{Innledning}

Hittil har skatteyters formål og kostnadens egnethet blitt behandlet som to etablerte kriterier i tilknytningsvurderingen. I det følgende behandles spørsmålet om også assosiasjonsverdien som oppnås gjennom et sponsorsamarbeid kan utgjøre et moment som bidrar til å oppfylle tilknytningsvilkåret.

Det å oppnå assosiasjonsverdi blant kundemassen kan utgjøre et avgjørende motiv bak sponsorsamarbeidet. ${ }^{103}$ Samtidig bærer ikke assosiasjonsverdi preg av å være en håndgripelig motytelse. Videre er det ingen konsensus i markedsføringsmiljøer rundt den bedrifts$\emptyset$ konomiske betydningen av assosiasjonsverdi. ${ }^{104}$ Når assosiasjonsverdien likevel er så sentral i et sponsorsamarbeid, skaper dette særlige spørsmål ved tilknytningsvurderingen.

Da Skagen anførte at det forelå tilstrekkelig tilknytning mellom den omstridte prosjektstøtten og deres inntekt, ble dette begrunnet $\mathrm{i}$ at prosjektstøtten ville skape assosiasjonsverdi for selskapet. ${ }^{105}$ Dette ble som kjent ikke godtatt av Høyesterett fordi det ikke forelå tilstrekkelig håndgripelige motytelser som lot seg verdsette. Høyesterett viste i denne sammenheng til dommen inntatt i Rt. 2008 s. 794 (Korsvold), der det i forbindelse med vurderingen av tilknytningsvilkåret ble uttalt at "dersom det bare påberopes generelle og lose utsagn om fremtidige inntektsmuligheter, vil tilknytningsvilkåret vanskelig bli ansett opp$f y l t "{ }^{106}$ Det kan spørres om assosiasjonsverdien kan tre inn som et substitutt for den håndgripelige motytelsen. For å vurdere dette er det først nødvendig å gå nærmere inn på hva assosiasjonsverdi er.

\footnotetext{
${ }^{103}$ Skard, Siv. 2009: "Sponsing - tid for å åpne den sorte boks". Kampanje 1.

${ }^{104}$ Ibid.

${ }^{105}$ Se Rt. 2012 s. 744, avs. 55.

${ }^{106}$ Rt. 2008 s. 794 , avs. 47.
} 


\subsection{Begrepet assosiasjonsverdi}

Assosiasjonsverdi kan beskrives som verdien for en bedrift eller person, av å bli assosiert med noe eller noen. En positiv assosiasjonsverdi kan innebære at offentligheten forbinder en bedrift eller et produkt med noe de selv opplever som positivt. Det kan for eksempel dreie seg om en dekkprodusents verdi av å bli assosiert med verdens beste formel 1-kjører. Publikum beundrer utøverens prestasjoner, og oppfatter at dekkprodusenten spiller på lag med utøveren. Med denne linken mellom sponsor og sponsorobjekt, søker sponsor å selge flere dekk til publikum. Forbindelsen mellom sponsor og - objekt trenger imidlertid ikke å være like åpenbar. Eksempelet om sponsorsamarbeidet mellom Mercedes-Benz og Den norske opera viser dette. Også her forsøker sponsor å få publikums begeistring og positive opplevelse av operabesøket til å smitte over på seg selv.

I mange sponsorsamarbeid skapes assosiasjonsverdi ved at sponsor yter et bidrag til sponsorobjektet, for at dette bidraget skal skape oppmerksomhet blant publikum. Oppmerksomheten kan forsterkes ved at bidraget promoteres i en situasjon hvor fokus er rettet mot bidragsyter. Dette kan gjøres gjennom ordinær reklame som viser og fokuserer på at bidraget har blitt gitt. Et eksempel på dette er at Toyota Australia gjennom en årrekke har gitt $\varnothing$ konomiske bidrag til det årlige miljøarrangementet "National Tree Day". ${ }^{107}$ Toyota fremhever videre denne støtten i markedsføringen av egne biler. ${ }^{108}$ Hensikten bak støtten er at publikum skal assosiere Toyota med miljøvennlige biler og med dette $\varnothing$ ke salget. Gjennom denne formen for markedsføring kan det hevdes at man enklere når frem til publikum med et budskap, enn ved tradisjonell reklame. Sponsor må da betale både for reklameplassen, og for bidraget som ytes til sponsorobjektet. I markedsføringsmiljøer betegnes promoteringen av bidraget gjerne som aktivering av sponsoratet. ${ }^{109}$

${ }^{107} \mathrm{Se}$ http://treeday.planetark.org/about/meetsponsors.cfm [Sitert 29.10.2012].

${ }^{108} \mathrm{Se}$ http://www.toyota.com.au/tree-day/toyotascommitment?wt.ac=Toyota_Events_NationalTreeday_TopNav_ToyotaCommitment [Sitert 29.10.2012].

${ }^{109}$ Skard, Liv, 2010: "Communication Effects in Sponsorships: An assessment of how different communication strategies can enhance incongruent sponsorships". http://brage.bibsys.no/nhh/handle/URN:NBN:nobibsys brage 23766 [Sitert 29.10.2012]. 
Det kan også tenkes eksempler der man ikke betaler for reklame, men fremmer sponsorsamarbeidet $\mathrm{i}$ andre situasjoner hvor man har publikums oppmerksomhet. Dette kan for eksempel være under en pressekonferanse i forbindelse med lanseringen av et nytt produkt. Et eksempel ville være dersom Volvo under en pressekonferanse hadde annonsert at de gir et økonomisk bidrag til foreningen Trygg Trafikk. Volvo kunne i denne forbindelse fortelle et samlet pressekorps at Volvo er opptatt av trafikksikkerhet, og at de derfor ønsker å gi dette bidraget. Volvo har med dette ikke betalt for reklametid på TV, eller for annonseplass i avisen. Det foreligger således ingen motytelser fra sponsorobjektet. Med bidraget til Trygg Trafikk søker man imidlertid å skape en oppfatning blant publikum om at den lanserte bilmodellen er en trafikksikker bil, uten at publikum nødvendigvis forstår at de har blitt utsatt for reklame.

\subsection{Rettslige virkninger av assosiasjonsverdien som tilknytningsmoment}

Fradragsretten for sponsorutgifter er som tidligere nevnt begrenset til sponsoratets reelle reklameverdi. ${ }^{110}$ Assosiasjonsverdiens uhåndgripelige natur medfører imidlertid at den ikke uten videre kan konverteres til "reell reklameverdi".

Prinsippet om fradragsrett kun for reell reklameverdi kan tenkes anvendt i eksempelet om Toyota. Fradraget ville etter dette prinsippet bli begrenset til reklameutgiftene man pådro seg i forbindelse med promoteringen av støttebidraget (aktiveringen). Begrensningen i fradraget skyldes at assosiasjonsverdien som oppnås ved sponsoratet ikke kan verdsettes på samme måte som rubrikkannonser og annen tradisjonell reklame. Man ville således ikke fått fradrag for støttebidraget i seg selv. I eksempelet om Volvo ville man etter den samme tilnærmingen ikke fått fradrag overhodet. Dette skyldes at man her kun har assosiasjonsverdien av sponsoratet, og ingen andre motytelser som det kan beregnes reell reklameverdi

${ }^{110}$ Se avs. 3.5.3.3. 
av. Dette taler for at oppnådd assosiasjonsverdi ikke bidrar til å oppfylle vilkårene for fradragsrett.

Det skatterettslige prinsippet om at det ikke gis fradrag for gaver er også til hinder for at assosiasjonsverdien alene, er med på å oppfylle tilknytningsvilkåret. Prinsippet har støtte i ligningspraksis, og ble som kjent fulgt opp av Høyesterett i Skagen-saken. Når assosiasjonsverdien er alt sponsor ønsker å oppnå, uten å kreve en motytelse fra sponsorobjektet, medfører dette raskt at sponsormidlene betraktes som en gave. I eksempelet om Volvo, ville dette prinsippet medført at fradrag for den økonomiske støtten ville bli nektet. Dette skyldes at en motytelse verken kreves eller ytes fra bidragsmottaker. Dersom denne løsningen følges, gis det ikke fullt fradrag uavhengig av om støttebidragene ville ha skapt assosiasjonsverdi og $\varnothing \mathrm{kt}$ salg. Denne løsningen innebærer at skatteyters forretningsskjønn må vike for kravet om håndfaste motytelser.

Et synspunkt er imidlertid at assosiasjonsverdien kan utgjøre et slags substitutt for motytelsen som kreves etter tilknytningsvilkåret. Tanken er at assosiasjonsverdien som oppnås ved et sponsorbidrag, trer inn i stedet for motytelsen som tradisjonelt ville medført at tilknytningsvilkåret var oppfylt. I Skagen-saken blir det ikke foretatt noen inngående behandling av assosiasjonsverdiens rolle i tilknytningsvurderingen. I behandlingen av hva man oppnådde med den omstridte prosjektstøtten ble det imidlertid uttalt at det i denne saken "i beste fall" var "tale om en assosiasjonsverdi som Skagen ikke har gitt nevneverdig substans". ${ }^{111}$ Dette synspunktet harmonerer med kriteriet om tilstrekkelig håndgripelige motytelser. ${ }^{112}$ Uttalelsen kan imidlertid også tolkes slik at Høyesterett ikke utelukker at assosiasjonsverdi kan bidra til å oppfylle tilknytningskravet dersom den gis tilstrekkelig substans. Dette kan tenkes å være tilfellet dersom oppnådd assosiasjonsverdi kunne påvises ut ifra de objektive kjensgjerningene i saken. ${ }^{113}$ Dersom det ut ifra disse kjensgjerningene er klart at sponsor mener at oppnådd assosiasjonsverdi vil øke omsetningen, er det derfor mu-

\footnotetext{
${ }^{111}$ Se Rt. 2012 s. 744, avs. 62.

112 Se avs. 4.6.

${ }^{113}$ Se avs. 3.3.1.2.
} 
lig at assosiasjonsverdien likevel bidrar til å oppfylle tilknytningsvilkåret. I så fall må formålet om økt omsetning gjennom oppnådd assosiasjonsverdi fremgå tydelig av objektive kjennetegn, slik som formelle avtaler og strategidokumenter.

En betraktning er imidlertid at Høyesterett, i Skagen, i realiteten vurderer hvor egnet assosiasjonsverdien er, til å fremme skatteyters inntekt. I forbindelse med vurderingen av assosiasjonsverdien som oppnås, blir det som nevnt uttalt at "Det er jo ikke avtalt at mottakeren skal prestere noe som kan gi giveren grunnlag for inntekt." Assosiasjonsverdiens uhåndgripelige natur medfører at den kan betraktes som uegnet til å etablere noen tilknytning mellom sponsorutgiften og sponsors skattepliktige inntekt. Dette synspunktet forsterkes av Høyesteretts uttalelser om at en eventuell assosiasjonsverdi ikke er gitt nevneverdig substans, og at de ikke utgjør motytelser som lar seg verdsette. ${ }^{114}$ Det kan derfor tenkes at Høyesterett i realiteten betrakter assosiasjonsverdi som for lite egnet til å oppfylle tilknytningsvilkåret. Det er likevel ikke grunn til å avfeie assosiasjonsverdien som et moment som kan trekkes inn i fradragsvurderingen. Selv om assosiasjonsverdi alene ikke kan bidra til å etablere noen tilknytning, kan det tjene som et støtteargument. Særlig må dette være tilfellet dersom oppnådd assosiasjonsverdi fremgår som et uttalt formål i avtale- og strategidokumenter og andre objektive kjennetegn. Ut ifra Skagen-dommen er det uansett vanskelig å trekke noen slutning om hvorvidt Høyesterett generelt anser assosiasjonsverdi som for lite egnet til å fremme skatteyters inntekt.

Det ville for øvrig være vanskelig for ligningsmyndigheter å innrømme fradrag på grunnlag av oppnådd assosiasjonsverdi etter dagens beregningsmetode, basert på "reell reklameverdi". Dette utelukker imidlertid ikke at man kunne la begrepet "reell reklameverdi" favne noe bredere. Man kunne for eksempel medregne reklameverdien av pressekonferanser og intervjuer som ble brukt i aktivering av sponsoratet, målt i prisen for tilsvarende tid og plass i media. Man ville da i større grad kunne fange opp assosiasjonsverdien som ble oppnådd, og dermed ta mer hensyn til skatteyters forretningsskjønn i fradragsberegningen.

${ }^{114}$ Se Rt. 2012 s. 744 , avs. 56 og 62. 


\section{Oppsummering av tilknytningsvurderingen}

Tilknytningsvilkårets rolle i fradragsvurderingen for sponsorutgifter er nå behandlet.

Behandlingen viser at formål og egnethet er kriterier med tydelig relevans, imens assosiasjonsverdiens rolle er mer usikker. Skagen-dommen viser at en forutsetning for å få fradrag, er at de objektive kjensgjerningene i saken må tilsi at formålet med sponsorsamarbeidet er kommersielt. ${ }^{115}$ Skatteyter må derfor kunne dokumentere et kommersielt formål bak utgiftene. Usikkerheten rundt sponsingens evne til å fremme skatteyters inntekt medfører samtidig at et kommersielt formål ikke nødvendigvis er tilstrekkelig: Sponsingen må i tillegg vurderes som tilstrekkelig egnet til å fremme skatteyters inntekt. Selv om oppnådd assosiasjonsverdi er et avgjørende mål bak et sponsorsamarbeid, utgjør ikke dette et sikkert kriterium i tilknytningsvurderingen. I fradragsvurderingen er det derfor viktig å unders $\emptyset$ ke hvilke motytelser som er avtalt og dokumentert, og videre om disse skaper reell reklameverdi for sponsor. Håndgripelige motytelser etter sponsoravtalen kan for det første tilsi at formålet er kommersielt og ikke veldedig. For det andre medfører slike motytelser at kostnaden lettere betraktes som egnet til å fremme skatteyters inntekt.

${ }^{115}$ Se avs.3.3.1.2. 


\section{Sponsing - representasjon eller gave?}

\subsection{Innledning}

Retten til å kreve fradrag for sponsorutgifter etter hovedregelen i skatteloven $\S$ 6-1 er nå behandlet. Skatteloven kapittel 6 inneholder også andre fradragsbestemmelser, som presiserer, utvider og innskrenker hovedregelen om fradrag. Hva gjelder utgifter til sponsing antas $\S$ 6-21 om representasjon og § 6-50 om gaver til frivillige organisasjoner å ha relevans. Disse bestemmelsene ble også anført av staten i Skagen-saken. ${ }^{116}$ Spørsmålet som reises i dette kapittelet er om og i tilfelle hvordan disse to bestemmelsene påvirker fradragsretten for sponsorutgifter.

\subsection{Sponsorutgifter og representasjon}

I Skagen-saken ble det anført av ligningsmyndighetene og staten at dersom de omstridte sponsorytelsene ikke skulle betraktes som gaver, måtte de ansees for å være representasjon. Ettersom Høyesterett kom til at tilknytningsvilkåret i $\S$ 6-1 ikke var oppfylt, ble ikke spørsmål om representasjon behandlet i Høyesterett.

Bestemmelsen om representasjon i § 6-21 oppstiller et rettslig utgangspunkt om at "Fradrag gis ikke for representasjon". I forarbeidene er representasjon definert som "utgifter som en bedrift pådrar seg for å få sluttet forretninger eller for å knytte eller bevare forretningsforbindelser. Det dreier seg således om kostnader som bedriften har utad overfor personer som ikke er knyttet som medarbeidere til bedriften.". 117

En alminnelig språklig forståelse av definisjonen tilsier at representasjon omhandler utgifter som brukes på kunder og andre forretningsforbindelser for fortsatt å kunne gjøre forretninger med dem. Kostnader til representasjon er dermed ikke fradragsberettiget selv om de

\footnotetext{
116 Se Rt. 2012 s. 744, avs. 35-37, samt avs. 64.

117 Ot.prp. nr. 20 (1973-74).
} 
har til formål å fremme skatteyters inntekt. Bestemmelsen er således en innskrenkning av hovedregelen om fradrag i $\S 6-1$.

Representasjon vil typisk være utgifter som pådras ved at man tar med kunder eller andre forretningsforbindelser på restaurantbesøk og lignende. ${ }^{118}$ Hensikten er gjerne å pleie kunderelasjoner for å bevare forretningsforbindelsene. Det kan også dreie seg om bevertning for å pleie forhold med pressen ved pressekonferanser og lignende. ${ }^{119}$ Formålet bak representasjonsregelen er at en fradragsrett for slike utgifter medfører en fare for at representasjonen i realiteten er personlig forbruk. ${ }^{120}$

Ut ifra definisjonen på representasjon, er det ikke åpenbart at § 6-21 er relevant i forbindelse med utgifter til sponsing. Sponsorutgifter er ikke noe en bruker direkte på konkrete kunder eller presseforbindelser, men på et objekt som videre skal henvende seg til kundemassen. Et konkret eksempel tjener til illustrasjon: Drikkevannsprodusenten Voss Water selger flaskevann i Norge til omtrent 80 kroner per liter. ${ }^{121}$ Samtidig sponser de et prosjekt som arbeider for å gi rent drikkevann i Afrika. ${ }^{122}$ Dette gjør imidlertid ikke Voss Water for å selge sitt eget vann til prosjektet i Afrika. Derimot gjøres dette formodentlig for å selge flere flasker vann i Norge. Til forskjell fra representasjon, er målgruppen for sponsorkampanjen dermed en annen enn de som mottar sponsormidlene. Etter dette ser ikke sponsorutgifter ut til å passe inn under definisjonen av representasjon. I tillegg kommer det at sponsorutgifter heller ikke rammes av formålet med representasjonsbestemmelsen. Sponsorutgifter er normalt kontantoverføringer som betaling til sponsorobjektet, og kan dermed ikke forveksles med utgifter til privat forbruk på samme måte som med utgifter til representasjon.

\footnotetext{
${ }^{118}$ Lignings-ABC 2012 s. 1095.

${ }^{119}$ Se Gjems-Onstad, Norsk Bedriftsskatterett, 2012, s. 310.

${ }^{120}$ Se Zimmer, 2009, s. 224.

${ }_{121} \mathrm{http}: / /$ www.nettavisen.no/nyheter/article2800867.ece (Sitert 01.10.12).

122 http://www.vosswater.com/index.php/responsibility/social/ (Sitert 01.10.12).
} 
Representasjonsbestemmelsen i skatteloven $§ 6-21$ er supplert av en forskrift som nærmere regulerer fradrag for utgifter til representasjon. ${ }^{123}$ Etter forskriftens $\S 6-21-1$ (2) presiseres det at "med representasjon menes tiltak som henvender seg utad til personer, bedrifter mv. som ikke er knyttet til bedriften". Denne definisjonen ser ikke ut til å innebære noe avvik fra definisjonen på representasjon fra forarbeidene. Det avgjørende etter begge definisjoner, er at "tiltaket" er rettet mot andre enn ansatte og $\emptyset$ vrige med en lignende tilknytning til bedriften. Etter forskriftens $§ 6-21-4$, gis det ikke fradrag for "gaver" til "kunder eller forretningsforbindelser eller deres familie". Denne bestemmelsen understreker det skatterettslige utgangspunktet om at det ikke gis fradrag for gaver. En gave fra sponsor til sponsorobjekt rammes dermed av bestemmelsen, og kommer ikke til fradrag. Dersom en sponsorutgift først betegnes som en gave etter hovedregelen i § 6-1, viser Høyesterett i Skagen-saken at fradrag nektes allerede av denne grunn. Forskriftens regulering av gaver som representasjon har dermed begrenset praktisk betydning for sponsorutgifter.

I Skagen-saken anførte staten subsidiært at bestemmelsen om "Reklame, gavegjenstand mv." i forskriftens $\S 6-21-5$ måtte medføre at den omstridte prosjektstøtten ikke var fradragsberettiget. Det fremgår av bestemmelsen at det ikke gis fradrag for kostnader til "annonser i blader som utgis av foreninger, hvis det betales vesentlig mer enn en naturlig annonsepris skulle tilsi". Det samme gjelder "andre former for reklame hvis vederlag ikke kan antas fastsatt på forretningsmessig grunnlag". Ordlyden synes å ta sikte på å ramme annonser som kjøpes til overpris for å støtte veldedige foreninger mv. Forutsetningen for at kostnaden skal anses som representasjon er dermed at kostnaden ikke er forretningsmessig begrunnet. Vurderingskriteriet ser dermed ut til å samsvare med vilkåret om kommersielt formål etter hovedregelen om fradrag i sktl. § 6-1. Når det gjelder utgifter til sponsing må man dermed også etter forskriften foreta en formålsvurdering for å kartlegge om sponsors hensikter er kommersielle. Forskriften påvirker imidlertid ikke fradragsadgangen på dette punktet, fordi et rent veldedig formål uansett ikke ville medføre fradragsrett etter $\S 6-1$.

${ }^{123}$ FOR 1999-11-22 nr 1160: Forskrift fastsatt av Skattedirektoratet til utfylling og gjennomføring mv. av skatteloven av 26. mars 1999 nr. 14. § 6-21. 
Forskriftens regel om at fradraget for markedsføring er begrenset til reell reklameverdi harmonerer med ligningspraksis. Dette styrker oppfatningen om at denne begrensingen i fradraget er gjeldende rett.

Etter dette kan det se ut til at fradragsreglene om representasjon ikke medfører noen endring i retten til å kreve fradrag for sponsorutgifter. Det avgjørende for fradragsadgangen er om tilknytningskriteriet etter $§ 6-1$ er oppfylt eller ikke.

\subsection{Sponsorutgifter og gaver til frivillige organisasjoner}

Skatteloven $\S 6-50$ inneholder et unntak fra hovedregelen om at det ikke gis fradrag for gaver. Etter bestemmelsen gis det fradrag for gaver til veldedige organisasjoner etter nærmere bestemte vilkår. Om gavebegrepet i skatteretten refereres det til avsnitt 3.2.1. Fradraget som innvilges er begrenset til kr. $12000 \mathrm{i}$ året. ${ }^{124}$ Dette innebærer at regelen har begrenset relevans for bedrifter som bruker sponsing aktivt i sin markedsføring.

Forarbeidene til lovbestemmelsen kan imidlertid være relevante for spørsmålet om fradragsrett for sponsorutgifter. Forarbeidene kan nemlig si noe om hvorvidt lovgiver har ment å ta stilling til fradragsretten for kostnader der det ikke kreves en konkret, håndgripelig motytelse tilbake. Dette har dermed betydning for diskusjonen rundt hvorvidt assosiasjonsverdi kan sies å etablere tilknytning etter hovedregelen om fradrag i § 6-1. ${ }^{125}$

I følge forarbeidene er det imidlertid lite som tyder på at bestemmelsen i § 6-50 er ment å ta stilling til fradragsretten for sponsorutgifter. I forarbeidene fokuseres det på hvilke krav som bør stilles til gavemottaker. Hvilke motiver man har for å gi til organisasjonene fremstår ikke som et hensyn bak reglene. ${ }^{126}$ Bakgrunnen for bestemmelsen i $§ 6-50$ er at man

\footnotetext{
${ }^{124}$ Jf. § 6-50, 5. ledd.

125 Se Kap. 5.

${ }^{126}$ Se Ot.prp.nr.1 (1997-98), Kap. 15.
} 
$\emptyset$ nsket å styrke frivillige organisasjoners $\varnothing$ konomiske stilling. ${ }^{127}$ Bedrifters behov for profilering og markedsføring er heller ikke et hensyn som har blitt trukket inn i diskusjonen ved innføring og endringene i bestemmelsen. Dette taler for at lovgiver ikke har ment å regulere adgangen til å kreve fradrag for sponsorbidrag som også er kommersielt motivert. Dette, sammenholdt med det relativt lave maksimumsfradraget, innebærer at bestemmelsen har liten praktisk betydning for spørsmålet om fradragsrett for sponsorutgifter.

${ }^{127}$ Ot.prp. nr.1 (1999-2000), avs. 2.5.4. 


\section{Hensynene bak fradragsreglene i møtet med sponsing}

\subsection{Innledning}

De rettslige vilkårene rundt adgangen til å kreve fradrag for sponsorutgifter er nå behandlet. Dette avsluttende kapittelet omhandler i hvilken grad hensynene bak fradragsreglene er ivaretatt ved fradragsvurderingen for sponsorutgifter.

\subsection{Skatteevneprinsippet}

Retten til skattemessig inntektsfradrag er begrunnet i skattevneprinsippet. Prinsippet innebærer at skatteyter kun skal skattlegges for det vedkommende har igjen etter at utgiftene i forbindelse med inntektservervet er trukket fra. ${ }^{128}$ Ved skattereformen i 1992 var et sentralt hensyn at det var skatteyters reelle skatteevne som måtte legges til grunn ved beskatningen. ${ }^{129}$ Bakgrunnen var at de dagjeldende fradragsreglene hadde resultert i skatteplanlegging og investeringer som var lite samfunnsøkonomisk hensiktsmessige. Rent skattemotiverte investeringer dempet veksten i norsk økonomi. Ved sterkere fokus på reell skatteevne, kunne denne tendensen reduseres. I denne forbindelse spiller fradragsretten en sentral rolle. Uten fradragsrett for utgifter i forbindelse med inntektserverv, ville skatteyter kunne risikere å måtte betale skatt av en virksomhet som ikke ga overskudd. Skatteyter ville dermed sitte igjen med en negativ inntekt på grunn av skattebelastningen. Skatteevneprinsippet innebærer imidlertid samtidig at fradrag er utelukket for kostnader som ikke bidrar til skatteyters inntektservervelse. Den egentlige evnen til å betale skatt av inntekten påvirkes ikke av kostnader som ikke har tilknytning til skatteyters inntekt.

For sponsorutgifter aktualiseres skatteevneprinsippet dersom skatteyter pådrar seg sponsorutgifter for å øke omsetningen, men likevel ikke får fradrag. Hvis skatteyter pådrar seg sponsorutgifter med et reelt formål om å øke omsetningen og fradrag likevel nektes, innebærer dette at hensynet til skatteevnen ikke vinner frem. Dette medfører at sponsor i egne

\footnotetext{
${ }^{128}$ Se Zimmer (2009) avs. 7.1 jf. avs. 5.2.

${ }^{129}$ Ot.prp. nr. 35 (1990-1991), avs. 1.4.
} 
Øyne reduserer sin nettoinntekt tilsvarende $28 \%$ av sponsorutgiften. I praksis er det imidlertid opp til skatteyter å vise at det er en sammenheng mellom kostnaden og den skattepliktige inntekten, dersom dette byr på tvil. Etter ligningsloven $§ 8-1$ skal ligningsmyndighetene avgjøre hvilket faktisk forhold som skal legges til grunn for ligningen. ${ }^{130}$ Det fremgår av forarbeidene at ligningsmyndighetene videre skal legge til grunn "det faktiske forhold som de etter en samlet vurdering anser som det sannsynlig riktige". ${ }^{131}$ Skatteyter må derfor i praksis sannsynliggjøre at kostnaden har den nødvendige tilknytning til egen inntekt. Behovet for å regulere fradragsadgangen innebærer med dette at skatteyter selv må påvise at sponsorutgiftene er pådratt for å øke omsetningen, og at sponsorsamarbeidet har en viss evne til dette. Etter Skagen-dommen ser man hva Høyesterett legger vekt på i tilknytningsvurderingen for utgifter til sponsing. Selv om dommen i stor grad bygger på de konkrete forholdene i saken, gjør dommen det enklere for skatteyter å vite hva det legges vekt på i tilknytningsvurderingen. Skatteyter kan for eksempel i avtaleverket eller interne selskapsdokumenter, dokumentere forhold som viser at formålet bak sponsingen i realiteten er kommersielt.

Som tidligere nevnt er fradraget for sponsorutgifter begrenset til kostnadens reelle reklameverdi. Dette kan i realiteten medføre et misforhold mellom kostnaden skatteyter pådrar seg og fradraget som til slutt gis. Etter det som er skrevet om assosiasjonsverdi kan det tenkes at skatteevneprinsippet settes på prøve dersom det oppstår differanse mellom skatteyters og ligningsmyndigheters vurdering av markedsføringsverdien av et sponsorsamarbeid. Gjennom en metode som også tok hensyn til den reelle verdien av assosiasjonsverdi ville man kunne fange opp dette. Ulempen ved å skulle regne med assosiasjonsverdi er at dette sannsynligvis ville komplisere en allerede komplisert beregningsmetode ytterligere. Uenigheten i markedsmiljøer vedrørende den økonomiske betydningen av assosiasjonsverdi illustrerer dette. Likevel ville en noe bredere anvendelse av begrepet "reell reklameverdi", som nevnt i avs. 5.3, kunne skape en bedre balanse mellom skatteyters og lignings-

\footnotetext{
${ }^{130}$ Lov av 13.06.1980 nr. 24 om ligningsforvaltning (ligningsloven).

${ }^{131}$ Ot.prp. nr. 29 (1978-79) s. 100.
} 
myndigheters oppfatning av hvor mye av en sponsorutgift som er knyttet til skatteyters inntekt. Dersom de фvrige vilkår for fradragsrett forelå, ville en slik forståelse av begrepet dermed i større grad ta hensyn til skatteevneprinsippet ved fradragsberegningen.

\subsection{Provenyhensyn}

Adgangen til å kreve fradrag påvirker statens skatteproveny. Dette innebærer at en utvidelse av fradragsretten medfører reduserte inntekter for det offentlige. Spørsmålet her er i hvilken grad fradragsretten for sponsorutgifter slik den virker etter dagens forståelse av regelverket, er hensiktsmessig vurdert etter provenyhensyn.

Fordi en utvidelse av retten til fradrag for skatteyterne medfører mindre skatteinntekter for stat og kommune, er det viktig å vurdere de provenymessige konsekvensene ved utformingen og håndhevelsen av fradragsreglene. Selv om økt fradrag i utgangspunktet medf $\varnothing-$ rer reduserte skatteinntekter kan en utvidet fradragsrett bidra til å stimulere til private investeringer. Dette kan skape $\varnothing \mathrm{kte}$ inntekter, som igjen medfører et $\emptyset \mathrm{kt}$ grunnlag for beskatning. Ved utforming og praktisering av fradragsreglene er det derfor også relevant å se på de bedriftsøkonomiske konsekvensene for skatteyter. For sponsorutgifter vil disse hensynene være relevante, fordi en fradragsmessig favorisering av tradisjonell reklame til fordel for sponsing vil kunne påvirke skatteyters valg av markedsføringsmetode. Dersom det ikke gis fradrag for visse former for sponsing, vil dette påvirke skatteyters valg av markedsføringsstrategi. Et gitt sponsorsamarbeid kan etter dette fremstå som mindre gunstig for skatteyter, selv om mye skulle tale for at det ville medføre bedre omsetning enn tradisjonell reklame. Dette ville dermed kunne påvirke skatteprovenyet negativt dersom den aktuelle sponsoravtalen hadde vært lønnsom for skatteyters virksomhet.

Samtidig vil en utvidelse av fradragsretten til også å gjelde ensidige økonomiske bidrag fra en sponsor til for eksempel frivillige organisasjoner, kunne medføre en uønsket reduksjon i skatteprovenyet. Ved å åpne for fradrag for kostnader som bærer preg av å være gaver ville dette kunne medføre at private gaver til ideelle organisasjoner kreves fradratt i større grad enn det skatteloven $§ 6-50$ åpner for. 
Som forarbeidene til $§ 6-50$ viser, ligger det en rekke politiske hensyn bak denne ordningen, som strekker videre enn de rent provenymessige og skattepolitiske. Til illustrasjon av den politiske debatten rundt fradragsretten på området, har finansminister Sigbjørn Johnsen gitt utrykk for at en utvidet fradragsrett på dette området ikke er ønskelig fra hans side. I sitt svar på et spørsmål fra stortingsrepresentant Gunnar Gundersen, uttaler han følgende om en utvidet fradragsadgang for utgifter til sponsing:

"Ut fra et overordnet syn mener jeg at staten bør ha styring med hvilke tiltak og formål som skal tilgodeses med offentlige midler. Selv om private gaver i utgangspunktet ikke er offentlig midler, gjфr denne fradragsretten at staten blir en vesentlig bidragsyter gjennom tapte skatteinntekter. Et tak på fradragsretten for gaver til veldedige organisasjoner er naturlig både ut fra slike overordnede hensyn og for å unngå at private aktфrer kan formidle store offentlige midler til sine private, ideelle referanser." 132

Uttalelsen illustrerer at rekkevidden av fradragsretten for ulike typer sponsing til syvende og sist er et politisk spørsmål. Frem til en eventuell klargjøring i lovverket må skatteyter forholde seg til kriteriene for fradragsrett, som er gjennomgått i avhandlingen.

${ }^{132}$ Brev til Stortinget, 24.09.2010. Skriftlig spørsmål nr. 1758 fra Gunnar Gundersen om sponsing og fradragsrett til allmennyttige formål. 
9 Register

\section{$9.1 \quad$ Lover}

Lov om ligningsforvaltning 13. juni nr. 241980 (lignl.).

Lov om skatt av formue og inntekt 26. mars nr. 141999 (sktl.).

Lov om merverdiavgift 19. juni nr. 582009 (mval.).

\section{$9.2 \quad$ Forskrifter}

FOR 1999-11-22 nr 1160: Forskrift fastsatt av Skattedirektoratet til utfylling og gjennomføring mv. av skatteloven av 26. mars 1999 nr. 14.

\subsection{Forarbeider}

\subsubsection{Odelstingspreposisjoner}

Ot.prp. nr. 20 (1973-74).

Ot.prp. nr. 29 (1978-79).

Ot.prp. nr. 35 (1990-91).

Ot.prp. nr.1 (1997-98).

Ot.prp. nr. 86 (1997-98).

Ot.prp. nr.1 (1999-2000).

\section{$9.4 \quad$ Avgjørelser}

\subsubsection{Høyesterett}

Rt. 1949 s. 912

Rt. 1956 s. 1188

Rt. 1965 s. 956

Rt. 2005 s. 1434

Rt. 2007 s. 1822

Rt. 2008 s. 794

Rt. 2009 s. 1467

Rt. 2012 s. 744 


\subsubsection{Lagmannsrett}

Utv. 2011 s. 1380. Gulating lagmannsrett

\subsubsection{Tingrett}

Utv. 2008 s. 1278. Trondheim tingrett

Utv. 2010 s. 1434. Stavanger tingrett.

\section{$9.5 \quad$ Ligningspraksis}

Fløystad, Torstein. Ligningsbehandlingen for utvinnings- og rørledningsselskap for inntektsåret 1999. Oslo, 2001.

Klagenemnda for oljeskatt. Kjennelse 25.2.2002. "Fradrag for bidrag til Stavanger Domkirke".

Klagenemnda for oljeskatt. Kjennelse 25.2.2002. "Fradrag for utgifter til reklame /sponsorvirksomhet /gaver".

Klagenemnda for oljeskatt. Kjennelse 19.11. 2007. "Fradrag for bidrag til et kunnskapssenter".

Bindende forhåndsuttalelse fra Skattedirektoratet. BFU 23/10. Avgitt 9.9.2010.

\subsection{Stortingsvedtak}

F24.11.2011 nr. 1151 Stortingsvedtak om skatt av inntekt og formue mv. for inntektsåret 2012 (Stortingets skattevedtak) Kapittel 3.

\subsection{Litteratur}

Gjems-Onstad, Ole. Norsk Bedriftsskatterett. 8. utgave. Oslo, 2012.

Gjems-Onstad, Ole. Norsk Bedriftsskatterett Oslo, 2001. side 294 
Gran, Anne Britt og Hofplass, Sophie. Kultursponsing. 2007.

Lignings-ABC, 2012.

Zimmer, Fredrik. Lærebok i Skatterett. 6. utgave. Oslo, 2009.

Aarbakke, Magnus. Skatt på inntekt. Oslo, 1987.

\section{$9.8 \quad$ Artikler}

Cornwell, Weeks, Roy. 2005: "Sponsorship-linked Marketing: Opening the Black Box". Journal of advertising. Vol. 34 no. 2 p. 21-42.

Meenaghan, John A., 1983: "Commercial Sponsorship". European Journal of Marketing, Vol. 17 Iss: 7, p. 5-73.

M. J. Polonsky, R. Speed: Linked Sponsorship and cause related marketing, Complementarities and Conflicts. European Journal of Marketing. 2001. p. 1361.

Skard, Siv. 2009: Sponsing - tid for å åpne den sorte boks. Kampanje 1 .

Skard, Siv. 2011: "Hvordan virker egentlig sponsing?". Magma 4 (11).

Sveriges Annonsörer/Novus. 2012: "Klovna Känslor - Svenskarnas inställning til reklam".

Walliser, Björn: "An International Review Of Sponsorship Research: Extension and Update". International Journal of Advertising, 2003. Vol. 22, No1. p. 3. 


\subsection{Nettdokumenter}

Brev til Stortinget, 24.09.2010. Skriftlig spørsmål nr. 1758 fra Gunnar Gundersen om sponsing og fradragsrett til allmennyttige formål.

http://www.regjeringen.no/nb/dep/fin/dok/andre/brev/brev_stortinget/2010/Svar-pa-spm-

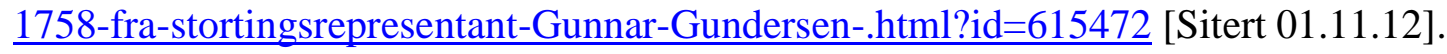

Brønn, Peggy Simcic, 2012: "Skal sponsing av sosiale tiltak gi skattefradrag?". Kampanje, 18.6.12. http://www.kampanje.com/kommentert/article6101802.ece. [Sitert 03.10.12].

Folkestad, Sigrid: "Mye å tjene på smartere sponsing". NHH Bulletin. http://www.forskning.no/artikler/2010/juni/252650 [Sitert 18.10.12].

Gimnes, Lasse: "Satte Red Bull på dagsordenen". Sponsor- og eventforeningen. http://sponsorogeventforeningen.no/sider/tekst.asp?side=694 [Sitert 17.10.12.].

IRM (Institutet för Reklam- och Mediestatistik), Norsk Mediestatistikk, 2011. http://www.irm-media.no/arsstatistikk.aspx [Sitert 14.09.12].

Lilleås, Heidi Schei. "Fra Madonna til Meny". Nettavisen. http://www.nettavisen.no/nyheter/article2800867.ece [Sitert 01.10.12].

Merverdiavgift - for veldedige og allmennyttige organisasjoner og institusjoner. Skattedirektoratet. Mars 2008.

http://www.skatteetaten.no/Upload/PDFer/Merverdiavgift/Brosjyreveldedige_2008.pdf [Sitert 12.09.12.].

Midsjø, Line: "Mercedes sponser Operaen". Kampanje.

http://www.kampanje.com/markedsforing/article5250637.ece [sitert 10.10.12].

National Tree Day. http://treeday.planetark.org/about/meetsponsors.cfm [Sitert 29.10.2012]. 
Skard, Siv, 2010: Communication Effects in Sponsorships: An assessment of how different communication strategies can enhance incongruent sponsorships.

http://brage.bibsys.no/nhh/handle/URN:NBN:no-bibsys_brage_23766 [Sitert 29.10.2012].

Tjømøe, Hans Mathias, 2010: Sponsing - forretning eller lek med penger. Magma 1 (10).

http://www.magma.no/sponsing-forretning-eller-lek-med-penger [Sitert 20.08.12].

Tjømøe, Hans Mathias. 2012. "- Hvordan virker sponsing?". Kampanje. 3.7.

http://www.kampanje.com/kommentert/article6133800.ece [Sitert 03.10.12].

Toyota Australia. http://www.toyota.com.au/tree-day/toyotas-

commitment?wt.ac=Toyota_Events_NationalTreeday_TopNav_ToyotaCommitment [Sitert 29.10.2012].

Voss Water. http://www.vosswater.com/index.php/responsibility/social/ [Sitert 01.10.12]. 